\title{
UČENJE OD GRADSKE KNJIŽNICE REYKJAVIK I ISLANDSKOG MODELA KNJIŽNIČNIH USLUGA METODOM JOB SHADOWING
}

\author{
USING JOB SHADOWING METHOD IN LEARNING FROM THE \\ REYKJAVIK CITY LIBRARY AND THE ICELANDIC MODEL \\ OF LIBRARY SERVICES
}

\section{Dijana Sabolović-Krajina}

Knjižnica i čitaonica „Fran Galovićc Koprivnica

dijana@knjiznica-koprivnica.hr

UDK / UDC

027.022(292.411):[303:001.8]

Stručni rad / Professional paper

Primljeno / Received: 24. 2. 2020.

Prihvaćeno / Accepted: 8. 6. 2020.

\section{Sažetak}

Cilj/svrha. Cilj je rada dati uvid u islandski model knjižničnih usluga s naglaskom na djelovanje Gradske knjižnice Reykjavik, najveće narodne knjižnice na Islandu.

Pristup/metodologija. Rabi se metoda studije slučaja koja je potkrijepljena rezultatima metode job shadowing ili neposrednog promatranja rada Gradske knjižnice Reykjavik tijekom stručnog usavršavanja autorice u programu neformalnog učenja stručnjaka Erasmus + , kao i metode analize dostupne relevantne literature (desk research). Rad daje uvid u kulturno-povijesni kontekst djelovanja islandskih knjižnica (pripadnost nordijskom kulturnom krugu, specifična tradicija čitanja, pismenosti i nakladništva, nacionalni knjižnični sustav i suvremeni konzorcij islandskih knjižnica), a potom pregled djelovanja Gradske knjižnice Reykjavik (organizacijska struktura, organizacijska kultura, knjižnični prostori, inovativni programi i projekti očuvanja kulturne baštine, poticanje čitanja u digitalnom okruženju, podupiranje interkulturnosti, poticanje kreativnog stvaralaštva - knjižnica kao maker space). U zaključku se daju preporuke za unapređenje rada hrvatskog knjižničnog sustava i knjižnica na temelju uvida u islandsku knjižničnu praksu.

Vjesnik bibliotekara Hrvatske 63, 1-2(2020), 523-554 ISSN 0507-1925 
Rezultati. Rad će poboljšati obaviještenost hrvatske knjižničarske zajednice o metodi job shadowing kao obliku neformalnog učenja i stručnog usavršavanja knjižničara, a ponajprije o organizaciji i funkcioniranju islandskog knjižničnog sustava te radu islandskih knjižnica koje pripadaju nordijskom kulturnom krugu s tradicijom visoko razvijenih javnih usluga. Ukazat će na napore islandskih knjižnica u suočavanju s ključnim društvenim izazovima, poput uključivanja imigranata u društvo i s padom čitateljskih kompetencija mladih u konkurenciji s drugim medijima.

Praktična primjena. Uvid u islandske načine racionalnog upravljanja ograničenim ljudskim, vremenskim i financijskim resursima knjižnica, koji se objedinjavaju na nacionalnoj razini, može poslužiti knjižnicama u Hrvatskoj kao primjer za unapređenje vlastite prakse. Također može poslužiti za benchmarking ili usporedbu osnovnih pokazatelja organizacije i usluga, a u cilju uvođenja promjena i poboljšanja rada kako bi se korisnicima ponudile što kvalitetnije knjižnične usluge u digitalnom okruženju.

Originalnost/vrijednost. Originalnost i vrijednost rada u širenju je spoznaja o modelima usluga i djelovanja islandskih knjižnica koje su u Hrvatskoj slabo poznate.

Ključne riječi: čitateljska kultura u digitalnom okruženju, Gradska knjižnica Reykjavik, islandski model knjižničnih usluga, job shadowing, program Erasmus+

\begin{abstract}
Aim/purpose. The aim of the paper is to give an insight into the Icelandic model of library services with an emphasis on the work of the Reykjavik City Library, the largest public library in Iceland.
\end{abstract}

Approach/methodology. The case study method is used, supported by the results of using the job shadowing method or direct observation of the work of the Reykjavik City Library during the author's professional training in the Erasmus + non-formal learning program. The method of analysis of the available relevant literature (desk research) is also used. The paper provides an insight into the cultural and historical context of Icelandic libraries (belonging to the Nordic cultural circle, with the specific tradition of reading, literacy and publishing, national library system and modern consortium of Icelandic libraries). An overview into the activities of the Reykjavik City Library is presented (organizational structure, organizational culture, library spaces, innovative programs and projects for preserving cultural heritage and encouraging reading in the digital environment, supporting interculturalism, encouraging creativity - library as a makerspace). In conclusion, some recommendations are given for improving the work of the Croatian library system based on the insights into the Icelandic library practice.

The results. The paper will improve the awareness of the Croatian library community about the job shadowing method as a form of informal learning and professional development of librarians, as well as the organization and functioning of the Icelandic library system and the work of Icelandic libraries belonging to the Nordic cultural circle with a 
tradition of highly developed public services. It will highlight Icelandic libraries' efforts to address key societal challenges, such as the inclusion of immigrants in society and the decline in young people's reading competencies in competition with other media.

Practical implications. An insight into Icelandic ways of managing limited human, time, and financial resources in order to provide users with the highest quality library services in a digital environment can serve to Croatian libraries as an example of good practice. It can also be used to benchmark organization and service indicators in order to bring changes and improve performance in providing users with the highest quality library services in a digital environment.

Originality/value. The originality and value of the work is in spreading knowledge about contemporary Icelandic libraries, which are relatively unknown in Croatia.

Keywords: Icelandic model of library services, job shadowing, program Erasmus + , reading culture in digital environment, The Reykjavik City Library

\section{Uvod}

U okviru koncepta cjeloživotnog učenja, kako ga promovira Europska unija svojim programima mobilnosti stručnjaka i stjecanja novog znanja, kompetencija i vještina neformalnim učenjem, metoda job shadowing ima istaknuto mjesto. Riječ je o obliku stručnog usavršavanja stručnjaka koji tijekom posjeta i boravka u izabranoj ustanovi promatraju i prate neposredni rad kolega na radnom mjestu te iz prve ruke proučavaju njihov svakodnevni posao, radno okruženje, metode i načine rada u praksi. Cilj je primijeniti primjere tuđe dobre prakse u vlastitom radu po povratku u vlastito radno okruženje. ${ }^{1}$

Islandski model knjižničnih usluga, kako ga primjenjuje Gradska knjižnica Reykjavik, zanimljiv je za stručno usavršavanje onim knjižničarima koji žele unaprijediti svoja znanja i vještine u suvremenom knjižničnom menadžmentu, upoznati se s njegovanjem kulturne baštine i promicanjem kulture čitanja u digitalnom okruženju, knjižničnim inkluzivnim programima i modelima strateškog partnerstva kojima knjižnice odgovaraju na izazove suvremenog društva. ${ }^{2}$ Za razliku od

1 Usp. Najčešća pitanja o Comenius aktivnostima: 11. Što je ,job shadowing”?. Dostupno na: http://arhiva.mobilnost.hr/index.php?id=202. [citirano: $2020-04-05$ ]

2 U Gradskoj knjižnici Reykjavik autorica je boravila od 16. do 24. 6. 2018. u okviru programa Erasmus+. Metodom job shadowing, odnosno promatranjem radnih procesa i organizacije rada Gradske knjižnice Reykjavik, dobila je uvid u način rada glavne knjižnice i četiri od pet knjižničnih ogranaka te bibliobusa. Uvidu u funkcioniranje te knjižnice doprinijeli su i razgovori $\mathrm{s}$ petnaest zaposlenika te knjižnice iz različitih strateško-menadžerskih razina, konkretno $\mathrm{s}$ direktoricom sustava narodnih knjižnica Reykjavika, voditeljicama knjižničnih ogranaka i glavne knjižnice, kao i voditeljima pojedinih službi i projekata, knjižničarima i mladim volonterima. Usp. Sabolović-Krajina, D. Posjet Gradskoj knjižnici Reykjavik u okviru programa Erasmus+, 16.-24. 6. 2018. // Svezak 21, 21(2019), 96-98. Dostupno na: http://www.drustvo-knjiznicara- 
mnogih zemalja u kojima je razina kulture čitanja u opadanju zbog konkurencije drugih medija, posebice interneta, čitanje knjiga na Islandu društveno je snažno poticana i poželjna aktivnost koja ima dugu tradiciju. Islanđani slove kao nacija čitatelja zato što se na Islandu po osobi knjige čitaju i objavljuju više nego bilo gdje drugdje u svijetu. ${ }^{3}$ Paralelno s čitanjem tiskanih knjiga, Island ima i jednu od najviših stopa uporabe internetskih i društvenih medija u svijetu, prema Svjetskom ekonomskom forumu. ${ }^{4}$ Zbog važnosti čitanja i pismenosti te popularnosti i slavljenja književnosti u svakodnevnom životu ${ }^{5}$ glavni grad Islanda Reykjavik 2011. godine izabran je za peti UNESCO-ov grad književnosti, priključivši se tako međunarodnoj mreži kreativnih gradova. ${ }^{6}$

Upravo je Gradska knjižnica Reykjavik svojim programima usmjerenima na knjige i autore u digitalnom okruženju jedna od glavnih nositelja tih međunarodno prepoznatih postignuća koje stvara u suradnji s mnogobrojnim partnerima. Ta knjižnica također je zanimljiva po svojoj organizacijskoj strukturi i organizacijskoj kulturi koja se zasniva na inovativnim poslovnim metodama i alatima u suočavanju s ograničenim ljudskim, financijskim i prostornim resursima s jedne strane te sofisticiranim potrebama korisnika u informacijskom dobu s druge strane.

bpkp.hr/svezak/svezak21/Svezak_21_2019.pdf. [citirano: 2019-11-15]; Sabolović-Krajina, D. Inkluzivne knjižnične usluge na primjerima Gradske knjižnice Rejkyavik i Knjižnice i čitaonice „Fran Galović“ Koprivnica. Dostupno na: https://ec.europa.eu/epale/hr/blog/posjet-gradskojknjiznici-reykjavik://ec.europa.eu/epale/hr/blog/inkluzivne-knjiznicne-usluge-na-primjerimagradske-knjiznice-rejkyavik-i-knjiznice-i-citaonice. [citirano: 2019-11-15].

3 Prema podacima koje navodi A. Wyman jedan od deset islandskih građana objavit će barem jednu knjigu tijekom svojeg života. Usp. Wyman, A. Participatory projects: Icelandic libraries. // IFLA Library, IFLA WLIC 2016, Ohio. Str. 2. Dostupno na: http://library.ifla.org/1385/1/079wyman-en.pdf. [citirano: 2019-11-15].

Islandske statistike pokazuju da se objavljuje pet naslova na svakih 1000 Islanđana, dok slične statistike za ostale nordijske zemlje pokazuju da se objavi 2 do 2,5 naslova na identičan broj stanovnika. Prosječan je broj naklade 1000 kopija za beletristiku, što je ekvivalent za milijun kopija u SAD-u. Usp. Publishing. // Reykjavik. Dostupno na: https://www.cityofliterature.nl/en/cities/ reykjavik/. [citirano: 2019-11-15].

Usporedbe radi, dok se na Islandu (384 000 stanovnika) godišnje objavi oko 1700 knjiga ili 5 knjiga na 1000 stanovnika, u Hrvatskoj (4 284889 stanovnika) u 2019. godini objavilo se 6294 knjige ili oko 1,5 knjiga na 1000 stanovnika. (izvor: Bibliografsko središte, Nacionalna i sveučilišna knjižnica u Zagrebu).

4 Usp. Wyman, A. Nav. dj., str. 3.

5 U popularnoj literaturi često se ističe kako je na Islandu knjiga na prvom mjestu izbora božićnih poklona. To je vrijeme kada je knjiga u središtu kulturnog i društvenog života Islanda. Riječ je o svojevrsnom kulturnom i komercijalnom fenomenu poznatom pod nazivom „božićna poplava knjiga“ (Jolabokaflod). Usp. Marić, A. Književni Island uživa uz tradicionalnu božićnu "poplavu knjiga" - Jolabokaflod (Christmas Book Flood). Dostupno na: https://citajknjigu.com/ knjizevni-island-uziva-uz-tradicionalnu-bozicnu-poplavu-knjiga-jolabokaflod-christmas-bookflood/. [citirano: 2019-11-15]; The Book-Flood-Before- Christmas. // Reykjavik.

Dostupno na: https://www.cityofliterature.nl/en/cities/reykjavik/. [citirano: 2019-11-15].

6 Usp. Reykjavík - City of literature. Dostupno na: https://www.cityofliterature.nl/en/cities/ reykjavik/. [citirano: 2019-11-15]. 


\section{Kulturno-povijesni kontekst djelovanja islandskih knjižnica}

Kulturno-društveni i povijesni kontekst u kojemu djeluju islandske knjižnice objašnjavaju četiri bitna čimbenika: pripadnost Islanda nordijskoj kulturnoj zajednici, specifična tradicija čitanja, pismenosti i nakladništva koja seže u srednjovjekovno doba, organizacija nacionalnog knjižničnog sustava i Konzorcij islandskih knjižnica kao glavno suvremeno organizacijsko obilježje suradnje islandskih knjižnica na nacionalnoj razini i odgovor na globalno digitalno okruženje.

\subsection{Pripadnost Islanda nordijskoj kulturnoj zajednici}

Island $^{7}$ pripada nordijskoj kulturnoj zajednici zajedno s Danskom, Finskom, Norveškom i Švedskom. Iako se te zemlje uveliko međusobno razlikuju po jeziku i nacionalnim kulturnim tradicijama, Jens Thorhaugeu ističe da ih povezuju mnoge zajedničke značajke i sličnosti u nasljeđu, razvoju i svakodnevnom životu, a između ostaloga tradicija javnog utjecaja na sve sfere života te tradicija protestantizma s isticanjem dužnosti i egalitarnosti i jakim utjecajem na rano širenje pismenosti i obrazovanja. ${ }^{8}$

Jedno je od zajedničkih obilježja nordijskih društava i duga tradicija djelovanja knjižnica, posebice narodnih knjižnica. ${ }^{9}$ Kao i u većini europskih narodnih knjižnica, korijeni im sežu u doba prosvjetiteljstva krajem 18. stoljeća kada privatni kolekcionari otvaraju svoje zbirke za javnost. U drugoj polovici 19. stoljeća otvaraju se javne knjižnice u pravom smislu riječi kao ustanove financirane javnim sredstvima. Nordijske knjižnice posebnu su pozornost svjetske javnosti privlačile svojim modelima poslovanja kojima su doprinosile izgradnji tzv. društva blagostanja od 1960-ih do 1980-ih godina, a potom prilagodbama

\footnotetext{
7 Island (Republika Island) otok je i država u sjevernom dijelu Atlantskog oceana, a nalazi se malo južnije od arktičkog kruga, između Grenlanda, Norveške i britanskih otoka. Prostire se na $103000 \mathrm{~km}^{2}$ i ima samo 348450 stanovnika, s najvećom koncentracijom oko glavnog grada Reykjavika s 222484 stanovnika (sam Reykjavik ima 124847 stanovnika). Usp. Iceland in figures 2018: volume 23. Reykjavík: Statistics Iceland, 2019. Dostupno na: https://hagstofan. s3.amazonaws.com/media/public/2019/7bc8b111-7479-4739-8aa5-a9b9f5dcf3eb.pdf.

[citirano: 2019-11-15].

Usporedbe radi, Island je površinom skoro dva puta veći od Hrvatske (56 $\left.594 \mathrm{~km}^{2}\right)$, a ima dvanaest puta manje stanovnika od Hrvatske (4 284889 stanovnika). Island ima najstariji parlament na svijetu, Althing (Alpingi), osnovan 930. godine. Na povijest i kulturu Islanda snažno je utjecalo gubljenje neovisnosti u 14. stoljeću kada potpada pod vlast Norveške, a potom zajedno s Norveškom pod vlast Danske. Posljednje veze političke ovisnosti s Danskom prekinute su 1944. godine kada je proglašena neovisna Republika Island. Usp. Island. // Mrežno izdanje Hrvatske enciklopedije Leksikografskog zavoda Miroslav Krleža.

Dostupno na: http://www.enciklopedija.hr/natuknica.aspx?id=27933. [citirano: 2019-11-15].

8 Thorhauge, J. The Nordic cultural sphere and the public libraries. // Nordic public libraries: The Nordic cultural sphere and its public libraries / editor Jens Thorhauge. Kobenhaven: The Danish National Library Authority, 2002., str. 9-12.

9 Isto, str. 12.
} 
informacijskom društvu. Promjena društvene paradigme uslijed informacijsko-tehnološkog razvoja odmah se odražava u knjižnicama uvođenjem mrežnih kataloga i usluga, a od sredine 1990-ih godina uvođenjem interneta kao javne usluge. Paralelno dolazi do strukturnih društvenih promjena, od kojih su tri najznačajnije. Prvo, odlukama lokalnih vlasti u nordijskim zemljama tijekom 1990-ih godina zatvoreno je 1000 ogranaka. Drugo, uvode se promjene u organizaciji regionalnih knjižničnih struktura kojima se zatvaranje mnogih manjih stacioniranih knjižnica nadoknađuje pokretnim knjižnicama i umrežavanjem u novim uslugama (poput „Pitajte knjižničare“, uslugama za djecu, etničke manjine, osobe s posebnim potrebama, malo i srednje poduzetništvo), kao i većom međusektorskom suradnjom, posebno s obrazovnim i nevladinim sektorom. Treće, uvodi se fleksibilnija međuknjižnična posudba kojom se također nadoknađuje zatvaranje mnogih manjih knjižnica, ali i racionalnije rabe postojeći knjižnični fondovi povećanom cirkulacijom i uporabom - građu je moguće naručiti na lokalnoj, regionalnoj i nacionalnoj razini i dopremiti razrađenim sustavima dostave (poštom, posebnim vozilima - bibliobusima, bibliobrodovima ili nekim drugim oblicima pokretnih usluga poput pakiranja torbi za dječje vrtiće, škole ili domove za starije ili kutijama s građom za brodove). U Hrvatskoj, primjera radi, sustav međuknjižnične posudbe još je uvijek trom i odvija se pretežno konvencionalnim kanalima, najčešće poštom. Ujedno je nedovoljno uporabljen resurs kako na županijskim, tako i na nacionalnoj razini i jedan od razloga zbog kojih po knjižnicama imamo pasivne i nedovoljno uporabljene fondove i pretrpanost prostornih kapaciteta s jedne strane, a neujednačenost i nejednakost $\mathrm{u}$ dostupnosti građe, posebice u dislociranim manjim naseljima.

Za razliku od hrvatskih knjižnica koje nisu dovoljno prepoznate u nacionalnim strateškim dokumentima kao pokretači društvenog razvoja, nordijske knjižnice imaju istaknuto mjesto u nacionalnom zakonodavstvu i strateškim dokumentima s jasno definiranim zadaćama, ulogama i očekivanjima u ispunjavanju ciljeva svojih vlada u razvoju informacijskog društva i društva znanja, a u skladu s nordijskom tradicijom javnog prosvjećivanja i javnog utjecaja na sve sfere života. ${ }^{10}$ Među najčešće su uporabljenim i najrazvijenijim knjižnicama u svijetu zahvaljujući ne samo umrežavanju i kooperaciji na lokalnim, regionalnim i nacionalnim razinama nego i integraciji mrežnih knjižničnih procesa i usluga, što još uvijek, posebice na nacionalnoj razini, nedostaje hrvatskom knjižničnom sustavu i nekoliko desetljeća nakon informatizacija knjižnica. Nordijske zemlje odlikuje i visok postotak obuhvata stanovništva u članstvu knjižnica (više od 50 posto), a važan razlog leži u zakonom propisanoj besplatnoj uporabi bar temeljnih knjižničnih usluga (posudbe građe). U Hrvatskoj to nije slučaj, a obuhvat stanovništva u članstvu narodnih knjižnica od 1990-ih godina nepromijenjen je i iznosi oko 12 posto.

10 Isto. 


\subsection{Tradicija čitanja i pismenosti}

Uz pripadnost nordijskom kulturnom krugu, drugi bitan čimbenik koji pridonosi razumijevanju ne samo suvremenog djelovanja islandskih knjižnica u poticanju čitanja nego i današnje skoro stopostotne stope pismenosti islandskog stanovništva, specifična je tradicija čitanja i kultura pričanja priča, tzv. saga. ${ }^{11}$ Upravo je srednjovjekovna književnost imala važnu ulogu u islandskoj društvenoj memoriji i održavanju kulturnog i nacionalnog identiteta stanovnika ovog izoliranog otoka na sjeveru Europe. ${ }^{12}$ Sigrún Klara Hannesdóttir ukazuje da postoje mnoga parcijalna objašnjenja tog fenomena (izolirani način života, duge zimske noći, utjecaj crkve, islandski jezik koji se nije mnogo promijenio u odnosu na drevna vremena pa moderni Islanđani još uvijek mogu relativno lako čitati izvorne srednjovjekovne tekstove). ${ }^{13}$

Velik utjecaj na širenje znanja i čitanja na Islandu imalo je, kao i u mnogim drugim zemljama, prihvaćanje kršćanstva do kojega je na Islandu došlo 1000. godine (tri stoljeća kasnije nego kod Hrvata), uz osnivanje i organiziranje crkvi s prvim školama za obrazovanje svećenstva.

Tiskarstvo je također stiglo na Island kasnije nego u ostalim zemljama Europe, gotovo stoljeće nakon Gutenbergova otkrića tiskarskog stroja, oko 1530. godine. Prva knjiga tiskana na islandskom jeziku bila je Biblija 1540. godine. Sigrún Klara Hannesdóttir također ukazuje da je u 18. stoljeću, usprkos prirodnim i socijalnim katastrofama, jedna trećina islandskog stanovništva znala čitati, da bi do 1800 . gotovo cijela nacija znala čitati. Usporedbe radi, do širenja pismenosti među hrvatskim stanovništvom dolazi obrazovnim reformama u drugoj polovici 19. stoljeća, a naročito kampanjama masovnog opismenjavanja nakon Drugog svjetskog rata.

Dok su preteče narodnih knjižnica u Hrvatskoj bile ilirske čitaonice u 19. stoljeću, tradicija i povijest islandskih knjižnica ima korijene u čitateljskim društvima kao prvim oblicima organiziranog čitanja na Islandu. Prvo je osnovano 1790. godine $^{14}$, da bi u razdoblju 1880. - 1920. osnovano sveukupno dvjesto čitateljskih društava u cijeloj zemlji, što je velik broj ako se uzme u obzir da je na prijelazu iz

11 Usp. Wyman, A. Nav. dj., str. 2.

12 Islandska književnost iz 12. i 13. stoljeća, poznata kao islandske sage i ede, jedinstvena je po tome što je pisana na islandskom jeziku u vrijeme kada je $u$ Europi jezik komunikacije bio latinski. Prva je poznata knjiga napisana na Islandu Knjiga zakona iz 1096. godine. Dva pisana izvora iz 12. stoljeća, Knjiga Islanđana (Íslendingabók) i Knjiga o naseobinama (Landnámabók), govore o doseljenju irskih redovnika na taj otok potkraj 8. te na početku 9. stoljeća kada su ga otkrili norveški Vikinzi i dali mu ime Ledena zemlja (Ísland).

13 Hannesdóttir, S. K. Books and reading in Iceland in a historical perspective. // Libraries \& Culture 28, 1 (1993), 13-21.

14 Glavna svrha prvog čitateljskog društva na Islandu bila je uvoz nove znanstvene literature $u$ zemlju koja je bila izolirana od glavnih kulturnih i znanstvenih tijekova tog vremena. Inicijalno su takva čitateljska društva bila ekskluzivna za svećenstvo i više društvene slojeve, s visokom članarinom i knjigama na stranim jezicima. U idućim desetljećima osnovano je više čitateljskih 
19. u 20. stoljeće na Islandu živjelo 78000 stanovnika, od toga 73 posto u ruralnim područjima zemlje.

\subsection{Islandski knjižnični sustav}

Višestoljetna politička vezanost Islanda uz Dansku do stjecanja potpune nezavisnosti 1944. godine odrazila se na islandsku kulturu i obrazovanje, pa tako i na formiranje islandskog knjižničnog sustava. ${ }^{15}$ Temelje mu čini osnivanje Nacionalne knjižnice Islanda 1818. godine na poticaj Islandskog književnog društva u Kopenhagenu. ${ }^{16}$ Sveučilišna knjižnica osnovana je 1940. godine, a obje knjižnice objedinjene su u zajedničkoj, novoj zgradi 1990. godine. Bogatu rukopisnu baštinu čuva Institut islandskih rukopisa.

Iako tradicija školskih knjižnica na Islandu seže u početke 20. stoljeća, njihovo sustavno organiziranje obvezno je zakonom od 1974. godine. ${ }^{17} \mathrm{U}$ manjim gradovima i mjestima školske i narodne knjižnice funkcioniraju kao kombinirane, zajedničke ustanove radi racionalnijeg i učinkovitijeg poslovanja, što bi također mogao biti poticaj za primjenu u Hrvatskoj kako bi se povećao obuhvat stanovništva članstvom u knjižnicama.

Nekoliko manjih specijalnih knjižnica potpora su istraživačkim centrima i specijaliziranim školama. Tzv. Nordijska kuća kulturni je centar čiji rad podupiru nordijske zemlje, a sadrži veliku zbirku vrijedne knjižnične građe. Islandska knjižnica za slijepe i slabovidne otvorena je 1983. godine. Proizvodi i distribuira građu na brajici i zvučne knjige. ${ }^{18}$

Prva narodna knjižnica osnovana je 1828. u gradu Akureyri na sjeveru Islanda. ${ }^{19}$ Većina regija na Islandu osnovala je svoje narodne knjižnice u prvim dvama desetljećima 20. stoljeća, pa je tako i Gradska knjižnica Reykjavik, najveća na Islandu, osnovana 1919. godine, a javnosti otvorena 1923. godine. Devedesetih godina 20. stoljeća na Islandu je djelovalo oko 230 narodnih knjižnica ${ }^{20}$, dok ih danas ima stotinjak, kao rezultat racionalizacije karakteristične za nordijska društva

društava, no većini stanovištva i nadalje su bila nedostupna. Prvo čitateljsko društvo za širu publiku, besplatno za sve, osnovano je 1833. godine. Usp. Hannesdóttir, S. K. Nav. dj., str. 18.

15 Ilustracije radi, prvi profesionalni knjižničari na Islandu svoje su obrazovanje stekli u inozemstvu, uglavnom u Danskoj, a prvi školovani knjižničar u Reykjaviku počeo je raditi 1923. godine.

16 Kjartansdóttir, A. Iceland. // World encyclopedia of library and information services: third edition. Chicago: American Library Association, 1993., str. 160- 161.

17 Lowrie, Jean E. School libraries and media centres. // Encyclopedia of library history / edited by Wayne A. Wiegand and Donald G. Davis. New York; London: Routledge Taylor \& Francis Group, 2013., str. 564. Kjartansdóttir, A. Nav. dj.

18 Isto.

19 Isto

20 Isto. 
nakon urušavanja države blagostanja. Organiziraju usluge u bolnicama, azilima i drugim institucijama te pripremaju kutije s knjigama za brodove. Prvi zakon o narodnim knjižnicama donesen je na Islandu 1955. godine. Zakon o narodnim knjižnicama iz 1997. definirao je ulogu narodnih knjižnica u informacijskom društvu, prije svega da svima omoguće slobodan pristup različitim zbirkama knjiga i drugih medija, uključujući računalne programe $\mathrm{i}$ informacije $\mathrm{u}$ digitalnom obliku. ${ }^{21} \mathrm{U}$ novoj knjižničnoj regulativi iz 2012. godine posebno se ističe suradnja kao neophodna pretpostavka ravnomjernog pružanja kvalitetnih knjižničnih usluga stanovništvu, uključujući i manja naselja bez stacioniranih knjižnica.

\subsection{Konzorcij islandskih knjižnica}

Glavno obilježje primjene zakonske obveze suradnje na nacionalnoj razini osnivanje je Konzorcija ${ }^{22}$ islandskih knjižnica (Landskerfi bókasafna hf.) 2001. godine. Konzorcij je odgovor islandske knjižničarske zajednice na suvremene informacijsko-tehnološke izazove s jedne strane, a s druge strane na potrebu racionalne uporabe i objedinjavanja ograničenih financijskih, ljudskih i vremenskih resursa relativno velikog broja knjižnica razasutih po Islandu, otoku sa samo 348 000 stanovnika. ${ }^{23}$ Vlasnik su Konzorcija islandska vlada i općine. Knjižnice plaćaju usluge Konzorcija ovisno o svojoj veličini. Među tristotinjak su institucija članica Nacionalna i sveučilišna knjižnica Islanda, knjižnice nekoliko manjih sveučilišta, većina narodnih knjižnica te knjižnice osnovnih i srednjih škola, kao i istraživačke i specijalne knjižnice. ${ }^{24}$

21 Libraries and archives. Dostupno na: https://www.island.is/en/education_and_society/culture_ and_the_arts/libraries_and_archives/. [citirano: 2019-11-15].

${ }_{22}$ Konzorcij (lat. consortium: zajednički imetak; zajednica), oblik ugovornoga povezivanja (udruživanja), u pravilu trgovačkih društava, redovito radi zajedničkog izvođenja investicijskih radova. Ugovorom o konzorciju uređuju se prava i obveze članova: podjela radova, rokovi za izvođenje, udio u troškovima, način odlučivanja u konzorciju, odgovornosti za neispunjenje posla, regresna prava i dr. Usp. Konzorcij. // Mrežno izdanje Hrvatske enciklopedije Leksikografskog zavoda Miroslav Krleža. Dostupno na: http://www.enciklopedija.hr/natuknica.aspx?id=33006. [citirano: 2019-11-15].

${ }^{23}$ Requirements list for a new library system (draft) Consortium of Icelandic libraries 19/2/2018. Dostupno na:https://www.landskerfi.is/sites/default/files/requirements_list_for_a_new_library_ system_draft__consortium_of_icelandic_libraries.pdf. [citirano: 2019-11-15]

${ }^{24}$ Osnovna struktura sustava jedan je bibliografski katalog i 12 administrativnih jedinica u koje je, prema stanju u 2016. godini, grupirano 306 knjižnica (narodnih knjižnica 84, srednjoškolskih knjižnica 22, osnovnoškolskih knjižnica 117 , sveučilišnih knjižnica 22, specijalnih knjižnica 61). Ilustracije radi, islandski nacionalni mrežni skupni katalog Gegnir do kraja 2016. godine sadržavao je 217686 bibliografskih zapisa knjiga, časopisa, članaka, glazbene i vizualne građu, 5 914538 jedinica građe te je zabilježio 3067395 posuđenih jedinica i 175242 korisnika, što čini 50-postotni obuhvat islandskog stanovništva. Usp. Requirements list for a new library system (draft). Consortium of Icelandic libraries 19/2/2018. Nav. dj. 
Zadaća je Konzorcija upravljanje središnjim mrežnim nacionalnim knjižničnim sustavom, a temelj mu je jedinstveni, skupni katalog za Island nazvan Gegnir ${ }^{25}$ te pružanje stručnih usluga islandskim knjižnicama. Skupni katalog povezan je na nacionalni portal za pretraživanje Leitir.is. ${ }^{26}$ Osim što omogućuje pristup raznolikim zbirkama islandskih knjižnica, povezan je i na kulturno-povijesnu bazu podataka $\mathrm{Sarpur}^{27}$, nacionalni muzejski katalog za katalogiziranje i snimanje artefakata, slika, arheoloških nalazišta, povijesnih građevina, naziva mjesta i kulturne povijesti za više od pedeset muzeja i institucija kulturne baštine na Islandu. Magnhildur Magnúsdóttir ističe jedinstvenost takvog radnog okruženja katalogizatora na Islandu u odnosu na mnoge druge zemlje jer suradnja knjižnica na nacionalnoj razini pomaže u pojednostavljivanju knjižničnih funkcija. ${ }^{28}$ Zbog toga bi islandski model mogao biti uzor Hrvatskoj koja još uvijek nema nacionalni mrežni skupni katalog s objedinjenim uvidom i mogućnošću pretraživanja fondova svih hrvatskih knjižnica, kao ni fondova ostalih baštinskih ustanova - muzeja i arhiva.

Za primjenu u Hrvatskoj zanimljiv je podatak da je temelj današnjem mrežnom nacionalnom knjižničnom sustavu postavio islandski konzorcij za pretplate na elektroničke časopise hvar.is, ${ }^{29}$ pokrenut krajem 1990-ih godina. ${ }^{30}$ Omogućuje pristup elektroničkim časopisima i bazama podataka (oko 10000 naslova). Važna mu je značajka da ne pruža pristup samo akademskim $i$ istraživačkim knjižnicama nego i svim knjižnicama na Islandu i svakome tko ima pristup internetu preko IP-adrese na Islandu. Kao primjer međusektorske suradnje može poslužiti i podatak da o nabavi elektroničke građe odlučuje povjerenstvo čiji članovi dolaze iz šest različitih područja - sveučilišnog, zdravstvenog, istraživačkog, srednjoškolskog, narodnih knjižnica i Nacionalne i sveučilišne knjižnice.

Hrvatskoj kao primjer može poslužiti i činjenica da je Konzorcij islandskih knjižnica uključen u nekoliko međunarodnih projekata i aktivnosti koji prate najnovije trendove u stručnoj obradi građe i njihovoj dostupnosti. Island je član Virtual International Authority File (VIAF) čiji je cilj sniziti troškove i povećati uporabu datoteka međunarodnim povezivanjem knjižnica. Osim toga Konzorcij

25 Gegnir. Dostupno na: www.gegnir.is. [citirano: 2019-11-15].

26 Leitir.is. Dostupno na: http://leitir.is.. [citirano: 2019-11-15].

27 Sarpur. Dostupno na: http://www.sarpur.is.. [citirano: 2019-11-15].

28 Magnúsdóttir, M. Community of cataloguers in Iceland. // Scandinavian Library Quaterly, 1-2(2016), 42-44. Dostupno na: http://slq.nu/wp-content/uploads/2016/06/SLQ-1-2.14.6.pdf. [citirano: 2019-11-15].

29 Hvar.is - Icelandic consortium for electronic subscriptions. Dostupno na: https://hvar.is/ english. [citirano: 2019-11-15].

30 Ólafsson, S. Iceland Consortia for electronic subscription. // Nordic public libraries in the knowledge society / J. H. Larsen (Ed.). København: Danish National Library Authority, 2006., str. 50-51. 
islandskih knjižnica primjenjuje od 2015. godine u mrežnom nacionalnom sustavu i skupnom katalogu nove standarde bibliografskog opisa, Resource Description \& Access (RDA), nakon opsežnih priprema koje sežu u 2007. godinu. Time se Island pridružio međunarodnim kretanjima u zamjeni kataloškog standarda MARC21 koji se rabio posljednjih tridesetak godina. ${ }^{31}$ Uvođenje kataloškog standarda RDA provedeno je pod vodstvom Nacionalne i sveučilišne knjižnice Islanda, ali u vrlo uskoj suradnji s knjižnicama uključenima u funkcioniranje nacionalnog knjižničnog sustava Geigner i rad Konzorcija koji je odgovoran za rad sustava, kao što su promjene $\mathrm{u}$ strukturi podataka $\mathrm{i} \mathrm{dr}^{32}$

Island kontinuirano prati potrebe poboljšanja rada knjižničnog sustava kako bi se izašlo ususret potrebama korisnika i knjižničara. Zbog brojnih promjena u tehnološkom okruženju u posljednjim dvama desetljećima Konzorcij islandskih knjižnica u proljeće 2018. godine objavio je natječaj za novi knjižnični sustav, uključujući platformu za pretraživanje, kako bi se zamijenio sadašnji Aleph iz sustava i usluga Ex Librisa. ${ }^{33}$

\section{Gradska knjižnica Reykjavik}

Gradska knjižnica Reykjavík (Borgarbókasafn Reykjavikur) ima posebno mjesto u islandskom knjižničnom sustavu kao najveća narodna knjižnica u zemlji, a ujedno i jedna od najstarijih kulturnih institucija u glavom gradu Islanda ${ }^{34}$.

Na temelju neposrednog uvida i praćenja rada Gradske knjižnice Reykjavik metodom job shadowing, kao i analizom dostupne literature (desk research), bit će predstavljena organizacijska struktura i organizacijska kultura te knjižnice, prostorne pretpostavke za rad te inovativni programi i projekti za očuvanje kulturne baštine, poticanje čitanja u digitalnom okruženju, podupiranje interkulturnosti te kreativno stvaralaštvo (knjižnica kao maker space).

\subsection{Organizacijska struktura}

Sastavnice organizacijske strukture Gradske knjižnice Reykjavik čine glavna knjižnica u središtu Reykjavika i pet ogranaka u prigradskim naseljima, bibliobus

\footnotetext{
31 Magnúsdóttir, M. Nav. dj.

32 Sveinsdóttir, S.; S. Hauksdóttir. Annual report from the Consortium of Icelandic Libraries for IGeLU National User group (INUG) 2018. Dostupno na: https://igelu.org/wp-content/ uploads/2018/08/Iceland-INUG-report-2018.pdf. [citirano: 2019-11-15].

33 Isto.

34 Torfadóttir, A. G. Borgarbókasafn Reykjavíkur. // Nordic public libraries: the Nordic cultural sphere and its public libraries / editor Jens Thorhauge. Københaven: The Danish National Library Authority, 2002. Str. 45-47.
} 
koji obilazi predgrađa i bibliokombi za pričanje priča djeci u dječjim vrtićima i školama. ${ }^{35}$

Glavna knjižnica i svaki od ogranaka imaju odjele ili korisničke prostore, tzv. zone aktivnosti za djecu, mlade i odrasle. Službe su zajedničke za cijeli knjižnični sustav i nalaze se u glavnoj knjižnici, a sastoje se od tri cjeline: Komunikacija i mediji, Usluge i razvoj te Uredski poslovi i menadžment. Cilj rada zajedničkih službi sa zaposlenim stručnjacima koji surađuju s knjižničnim osobljem na odjelima i u ograncima racionalno je i učinkovito upravljanje ljudskim resursima i vremenom te osiguravanje ujednačene ponude i kvalitete usluga i programa u svim sastavnicama Gradske knjižnice Reykjavik - kako u središnjoj knjižnici, tako i u ograncima. Ujedno se od takve organizacijske sheme zajedničkih službi za cijelu mrežu, koja također može poslužiti kao primjer dobre prakse hrvatskim knjižnicama, očekuje da bude temelj učinkovite, racionalne, inovativne i kreativne organizacijske kulture.

U službi Komunikacija $i$ mediji rade voditelj službe te voditelji književnih programa, izložbi i medija, događanja i komunikacije, publiciteta, interkulturnih projekata, mobilne pričaonice, izložbi i medija. Uz profesionalne knjižničare koji se bave osmišljavanjem i koordinacijom književnih programa, izložbi i ostalih događanja u knjižničnoj mreži, u toj su službi zaposleni stručnjaci koji nisu knjižničari, npr. profesionalna glumica - pripovjedačica priča ili storyteller - koja sama vozi bibliokombi obilazeći dječje vrtiće i osnovne škole te djeci pripovijeda priče i bajke, potom stručnjak za odnose s javnošću koji radi na publicitetu događanja koji se oglašavaju kroz konvencionalne kanale poput novina, TV-a i radija, ali i putem mrežnih stranica knjižnice, društvenih mreža i portala. U toj službi radi i stručnjakinja za interkulturnost koja osmišljava programe i projekte za višejezične korisnike i imigrante u cijeloj knjižničnoj mreži Reykjavika.

U službi Usluge i razvoj rade voditelj službe te voditelj inovacija i razvoja, digitalnih usluga i tehnologije, usluga i komunikacije te katalogizacije i bibliografskog nadzora. Na čelu te službe profesionalna je dizajnerica koja je završila i studij strateškog menadžmenta. Ona je ponajprije zadužena za konceptualnu i praktičnu primjenu novog, u knjižnicama diljem svijeta sve popularnijeg upravljačkog koncepta i poslovnog alata design thinking koji rabi kreativnost i suradnju u oblikovanju novih usluga, dizajniranju interijera te općenito u rješavanju poslovnih problema i izazova. ${ }^{36}$ Ta se služba bavi inovacijama u radu, uključujući i

35 Reykjavík City Library Culture Houses. Dostupno na: https://borgarbokasafn.is/en/bokasofn. [citirano: 2019-11-15].

36 Design thinking način je rješavanja nekog problema pomoću strukturiranog procesa te skupa metoda i tehnika koje izvorno potječu iz dizajna kao praktične i teorijske discipline. Usp. Antoljak, V.; M. Kosović. Design thinking za nedizajnere: kako riješiti poslovne probleme i uspješno inovirati. Zagreb: Školska knjiga: Sense savjetovanja, 2018., str. 29. 
logistiku informacijsko-komunikacijske tehnologije, kao i redefiniranjem i redizajniranjem postojećih usluga i prostornih pretpostavki.

Treća zajednička služba, Uredski poslovi i menadžment, pruža administrativnu logistiku radu cijelog knjižničnog sustava, a u njoj rade arhivist, dva administrativna tajnika i voditelj ureda.

$\mathrm{Na}$ čelu je knjižničnog sustava narodnih knjižnica grada Reykjavika ravnateljica ili tzv. glavna knjižničarka grada Reykjavika. To ukazuje da se za čelnu, ravnateljsku poziciju zahtijeva knjižničarsko obrazovanje, za razliku od najnovije hrvatske prakse, zasnovane na novom Zakonu o knjižnicama i knjižničnoj djelatnosti, po kojoj ravnatelj knjižnice nije obvezan imati formalno knjižničarsko obrazovanje. Voditelji knjižničnih ogranaka bave se operativnim poslovima, tj. koordinacijom i organizacijom svakodnevnih radnih zadataka i procesa, zaduženjima zaposlenika i raspodjelom njihova radnog vremena u pojedinim organizacijskim jedinicama. Neposredni rad s korisnicima obavljaju profesionalni knjižničari (npr. u glavnoj knjižnici Grófin ima ih pet) te pomoćno i tehničko osoblje. U usporedbi $\mathrm{s}$ hrvatskom praksom, u neposrednom radu s korisnicima radi manje knjižničara nego u hrvatskim knjižnicama, no njihova su zaduženja više stručno fokusirana, a manje disperzivna po vrstama različitih poslova koje obavljaju uz primarni posao (manje „svaštare“ nego hrvatski knjižničari). Knjižnica ima volontere tijekom ljetnih praznika - učenike srednjih škola koji su odabrali knjižnicu za odrađivanje prakse tijekom školskih praznika, koja je obvezna za sve učenike na Islandu. Knjižnica radi svih sedam dana u tjednu. Radno je vrijeme zaposlenika fleksibilno, što za organizatore rada iziskuje pedantno planiranje i koordiniranje satnice.

O visokoj razini zadovoljstva islandskih knjižničara na radnom mjestu ukazuju i rezultati provedenih istraživanja. ${ }^{37} \mathrm{Za}$ hrvatsku knjižničnu i radnu praksu zanimljiv je podatak o provođenju eksperimentalnog programa grada Reykjavika s reduciranom radnom satnicom za sat i pol tjedno u Gradskoj knjižnici Reykjavik, kao motivacijom da se u kraće vrijeme uradi isti posao, a istovremeno poveća zadovoljstvo zaposlenika. Nakon pozitivnih iskustava tijekom 2018. i 2019. godine sklopljen je sa zaposlenicima ugovor o smanjenom tjednom broju radnih sati, o čijem točnom broju (od jednog do četiri sata) još se pregovara, da bi se s primjenom krenulo početkom 2021. godine. Za razliku od hrvatske zakonske regulative, islandski zakon o radu dopušta takve oblike raspodjele radnog vremena, kao i zapošljavanje na smanjeno radno vrijeme. Svaki ogranak, kao i knjižnica u cjelini, imaju svoj proračun unutar kojega odabiru oblik zapošljavanja prema financijskim mogućnostima i potrebama na određeno i neodređeno radno vrijeme.

Za hrvatske knjižnice koje žele pospješiti posjećenost korisnika i uporabu svojih usluga koristan je i podatak da je članarina besplatna za osobe mlađe od osamnaest godina, osobe s invaliditetom i starije osobe, dok ostali trebaju

37 Usp. Wyman, A. Nav. dj., str. 4. 
platiti za Island, inače vrlo skupu zemlju, simboličnu naknadu od 2000 ISK (islandskih kruna) za knjižničnu iskaznicu (oko 110 kn). Mala naknada plaća se i za uporabu interneta u knjižnicama, dok je u većini hrvatskih knjižnica ta usluga besplatna. Prema dostupnim podacima Gradska knjižnica Reykjavik u 2015. godini zabilježila je 620000 posjeta i 900000 jedinica posuđene građe. ${ }^{38}$ S obzirom na 125000 stanovnika Reykjavika, proizlazi da je knjižnicu tijekom te godine svaki stanovnik posjetio pet puta i posudio više od sedam jedinica građe, što je izuzetno velik broj.

Gradska knjižnica Reykjavik ima dugu tradiciju pokretnih usluga zbog potrebe pružanja usluga u manjim, raspršenim gradskim naseljima udaljenima od stacioniranih knjižnica. Najstarija takva usluga bila je priprema kutija s knjigama za brodove budući da je ribarstvo tradicionalno najvažnija gospodarska grana na Islandu. Prvo bibliobusno vozilo s radom je počelo 1969. godine te ga se od tada zamjenjuje novim vozilima. Postojeće vozilo iz 2001. godine staro je čak 19 godina pa u starosti dijeli sličnost $\mathrm{s}$ većinom hrvatskih bibliobusa. ${ }^{39}$ Zanimljivo je spomenuti da je to jedino bibliobusno vozilo na Islandu koji, za razliku od nekih drugih nordijskih zemalja, nema bibliobrodove.

Kako je nordijska tradicija da se bibliobusima daju imena, taj se u prijevodu zove Šef, a ima i mlađeg brata pod nazivom Æringji, što otprilike znači Princezina kruna. To je biblio-kombi koji ima funkciju putujuće pričaonice. Iznutra je uređen za scenske nastupe već spomenute profesionalne glumice - pripovjedačice priča i njezinih gostiju, s dekoracijom (tamnim baršunastim zavjesama i oslikanim svodom poput neba sa zvijezdama) kako bi se stvorilo zabavno i uzbudljivo okruženje za pričanje priča. Uz ideju o specijaliziranoj usluzi bibliobusnog vozila, za hrvatske knjižnice koje imaju bibliobuse ili bibliokombije ili ih planiraju nabaviti može biti poticajna praksa te specifične putujuće pričaonice da ju se može uz naknadu rezervirati za gostovanja na festivalima i drugim događanjima u gradu.

Uz usluge bibliobusa Gradska knjižnica Reykjavik ima još jednu pokretnu uslugu od 1974. godine, a to je besplatna Kućna dostava knjiga nemoćnima i starima, koja također može biti koristan primjer hrvatskim knjižnicama budući da je ta usluga u u našoj sredini još uvijek rijetkost. Svakih osam tjedana korisniku se isporučuje paket od 10 do 15 knjiga koje bira knjižničar u suradnji s korisnikom.

Fleksibilnu cirkulaciju građe unutar gradske knjižnične mreže, kao i unutar svih članova Konzorcija islandskih knjižnica, omogućuje međuknjižnična posudba.

38 Libraries and open access to databases. Dostupno na: https://www.cityofliterature.nl/en/cities/ reykjavik/. [citirano: 2019-11-15].

39 Zanimljivo, kao primjer dobre prakse za hrvatske knjižnice, jest da je najstarije bibliobusno vozilo smješteno kao izložak u Muzeju transporta u Störagerði u Skagafjörðuru pa knjižnica poziva korisnike i građane da ga ondje posjete i ,prisjete se starih i dobrih vremena“. Usp. Torfadóttir, A. G. Nav. dj. 


\subsection{Organizacijska kultura}

Inovativnost, kao i širenje kruga partnera u suradnji sa zajednicom, glavne su odlike organizacijske kulture Gradske knjižnice Reykjavik. Te odlike ugrađene su kako u izgradnju knjižničnih zbirki, tako i u redefiniciju, adaptaciju i rekonstrukciju knjižničnih prostora glavne knjižnice i ogranaka (usporedi s poglavljem 3.3.). Ugrađene su također i u implementaciju informacijsko-komunikacijske tehnologije u knjižničnu ponudu te uvođenje novih projekata i programa kojima se izgrađuje kultura čitanja i čuva kulturna baština. Svakako treba spomenuti i programe potpore gradskoj politici njegovanja interkulturnosti, po kojima je ta knjižnica i međunarodno poznata, te implementaciju danas popularnog koncepta maker space (usporedi s poglavljem 3.4.).

Uz primjenu već spomenutog poslovnog koncepta i alata design thinking, inovativno i kreativno djelovanje knjižnice zasniva se i na drugim alatima u upravljanju knjižnicama, poput projektnog pristupa rješavanju problema i poslovnih izazova, timskog rada, racionalnog upravljanja ljudskim potencijalima (npr. outsourcing ili unajmljivanje komercijalnih kompanija za poslove čišćenja i pospremanja, uz uključivanje stalnog osoblja na odjelima u svakodnevno čišćenje i dezinficiranje knjiga bez obzira na stručnu spremu), upravljanje vremenom, upravljanje promjenama i dr.

\subsection{Prostor, oprema i smještaj građe}

Za hrvatske knjižnice inspirativna može biti praksa Gradske knjižnice Reykjavik u pristupu jednoj od bitnih radnih pretpostavki - fizičkom prostoru i njegovoj opremljenosti za rad s korisnicima i knjižničnom građom i medijima. Knjižnični prostor doživljava se prije svega kao izazov da se korisnicima ponudi ono što nije na računalnoj mreži te da knjižnica bude dovoljno atraktivna da zadrži interes i pažnju korisnika. Knjižnični prostori i zgrade funkcioniraju kao tzv. kuće ili domovi kulture, što je tipično za nordijsku tradiciju. Karakteristična je kolokacija ili dijeljenje prostornih resursa s drugim javnim institucijama unutar istog objekta. Tradicionalno se knjižnice smještaju u objekte koje stranovništvo posjećuje i zbog drugih svakodnevnih potreba. Tako knjižnični ogranak Gerðuberg, koji se nalazi u kvartu s većinskom imigrantskom populacijom, dijeli zgradu s obiteljskim centrom i domom za starije; ogranak Spöngin nalazi se u trgovačkom centru u blizini škola; knjižnični ogranak Kringlan dijeli zgradu s gradskim kazalištem i velikim trgovačkim centrom, dok se glavna knjižnica Grófin prostire na nekoliko katova zgrade u kojoj se još nalazi i muzej fotografija, kao i gradski arhiv. Jedino najstariji i najmanji ogranak Sólheimar ima vlastiti, montažni objekt koji potječe s kraja 1970-ih godina i nalazi se u u 
predgrađu, kvartu s radničkim stambenim zgradama. Novi ogranak planira se u sklopu objekta s bazenom za plivanje. Za razliku od hrvatske kulture življenja, gdje bi takav smještaj knjižnice izazvao čuđenje, na Islandu to nije slučaj, jer su bazeni za plivanje vrlo popularna i posjećena javna mjesta, uostalom kao i knjižnice. Na posjećenost knjižnica utječe i blizina drugih javnih institucija, posebice odgojno-obrazovnih poput dječjih vrtića i škola.

Glavnu knjižnicu i ogranke trenutno najviše obilježava redefinicija knjižničnih prostora, do koje se dolazi već spomenutom primjenom metode design thinking. Provodi se drugačiji razmještaj knjižnične opreme s ciljem povećanja atraktivnosti, uporabe i poboljšanja iskustva boravka u knjižnici. Da bi se dobilo više prostora za korisnike, reducira se broj polica s knjigama, a otpis knjiga, kao i u hrvatskim knjižnicama, ovisi o procjenama knjižničara s obzirom na prostorne kapacitete i potrebe korisnika pojedinih knjižnica. To je odraz paradigme suvremenog knjižničarstva koja nije više toliko fokusirano na zbirke, koliko na potrebe korisnika. Također je vrlo karakteristično za nordijske knjižnice, pa tako i za islandske, da se pokušava 70 posto prostora osigurati za korisnike, a samo 30 posto za knjige i ostalu građu. Prihvaćen je novi način smještaja na police - prednost se daje tematskom smještaju u odnosu na decimalnu, brojčanu klasifikaciju koja još uvijek prevladava u hrvatskim knjižnicama. Očekivani rezultat pojačana je cirkulacija građe, odnosno znatan obrt fonda i porast posudbe građe.

Zorna ilustracija primjene design thinkinga kao alata i procesa u preoblikovanju i adaptaciji prostora preuređeni je ulazni hol glavne gradske knjižnice Grofin (slika 1), koji je nakon toga dobio na funkcionalnosti, boljoj preglednosti ponuđenih usluga te atraktivnosti kombinacijom boja. Mijenja se i knjižnična oprema koja pridonosi racionalizaciji prostora i opuštenijoj atmosferi. Police su fleksibilne, na kotačima, tako da se lako uklanjaju u stranu kada se prostor prenamjenjuje za kulturno-knjižnična događanja i programe. Umjesto prenatrpanosti, na njima se ostavlja dovoljno prostora za izlaganje knjiga, kao što prikazuje slika 2. Prevladavaju pastelne boje namještaja i ugodni kutci sa sofama, dvosjedima, naslonjačima, ležaljkama (slika 3.), kao i visećim ljuljačkama (slika 4.). Svaki ogranak ima identifikacijsku boju koja se odražava u signalizaciji prostora, dizajnu namještaja i promotivnim materijalima. Sve knjižnice imaju izložbene dvorane za izlaganje slika i fotografija ponajprije lokalnih stvaralaca, profesionalaca i amatera, kao i prostore za događanja za djecu i odrasle te punktove s društvenim igrama, također za djecu i odrasle, poput na Islandu vrlo omiljenog šaha. Za razliku od većine hrvatskih knjižnica, sve knjižnice u Reykjaviku imaju stanice za samoposlugu u posuđivanju i vraćanju knjiga pa na tim rutinskim knjižničnim funkcijama ne zapošljavaju stručne radnike, što je još jedan primjer racionalizacije poslovanja. 


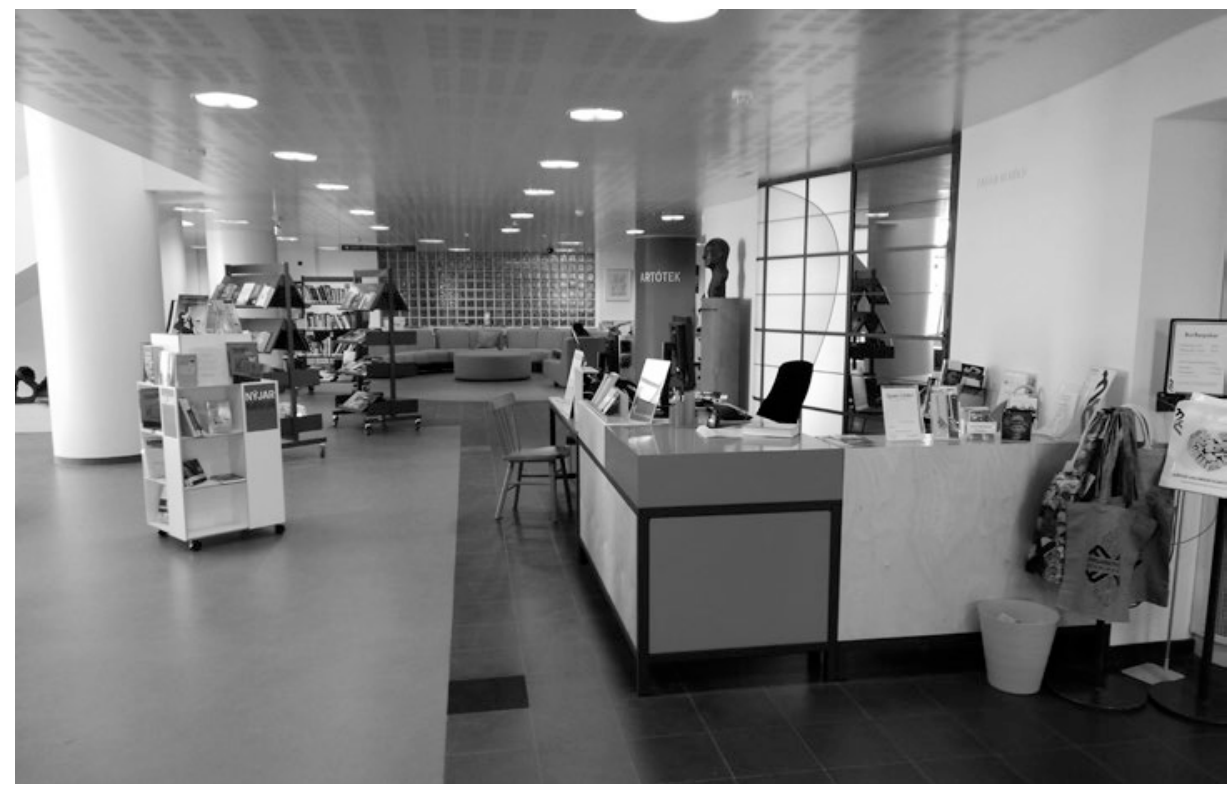

Slika 1.Ulazni hol glavne knjižnice Grofin s prijemnim pultom i artotekom

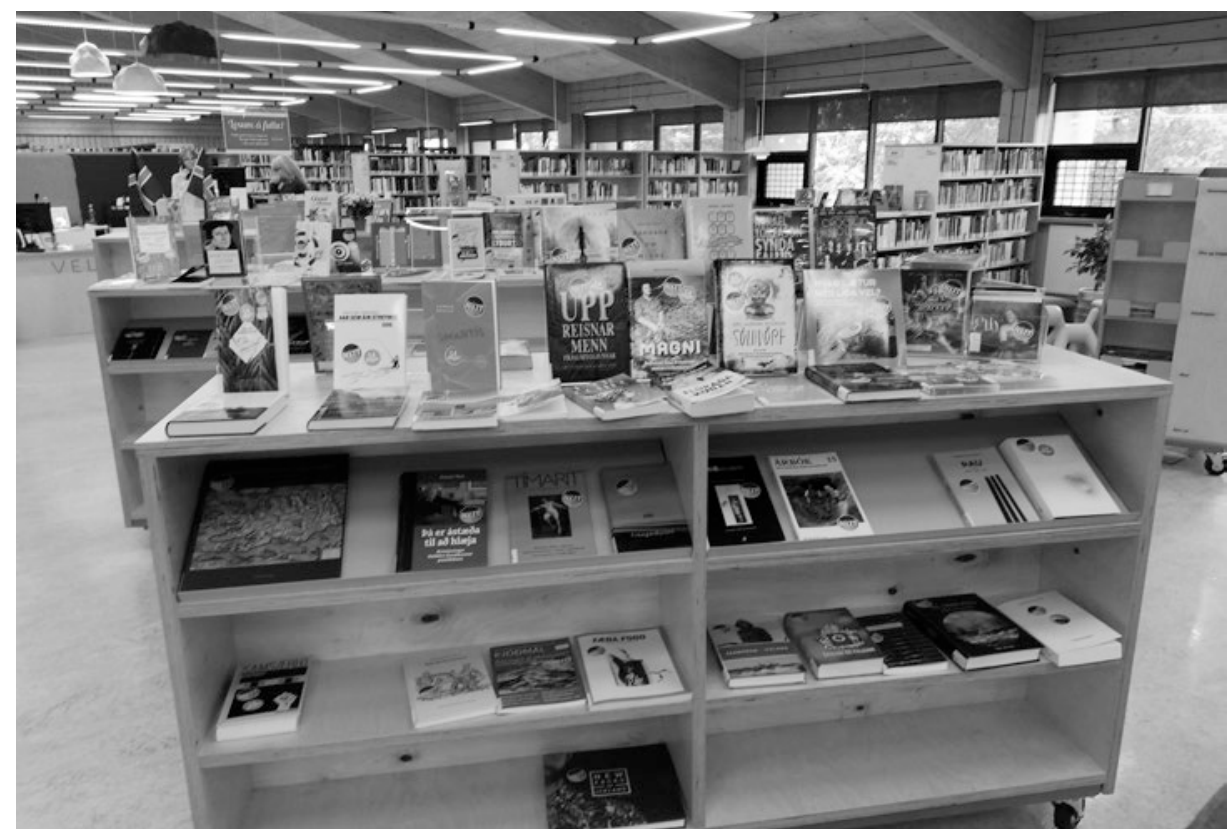

Slika 2. Smještaj fonda u posudbenom dijelu knjižničnog ogranka Gerðuberg 


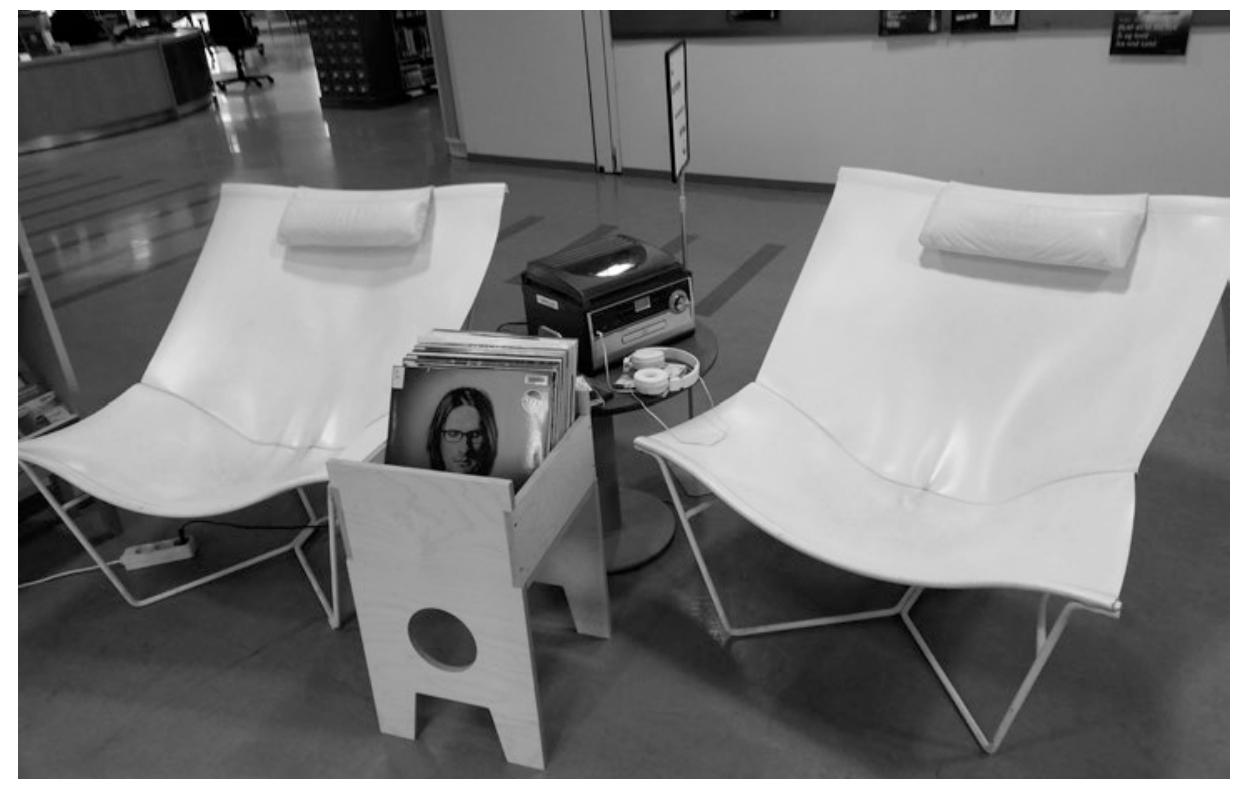

Slika 3. Kutak za slušanje glazbe u multimedijalnom odjelu glavne knjižnice

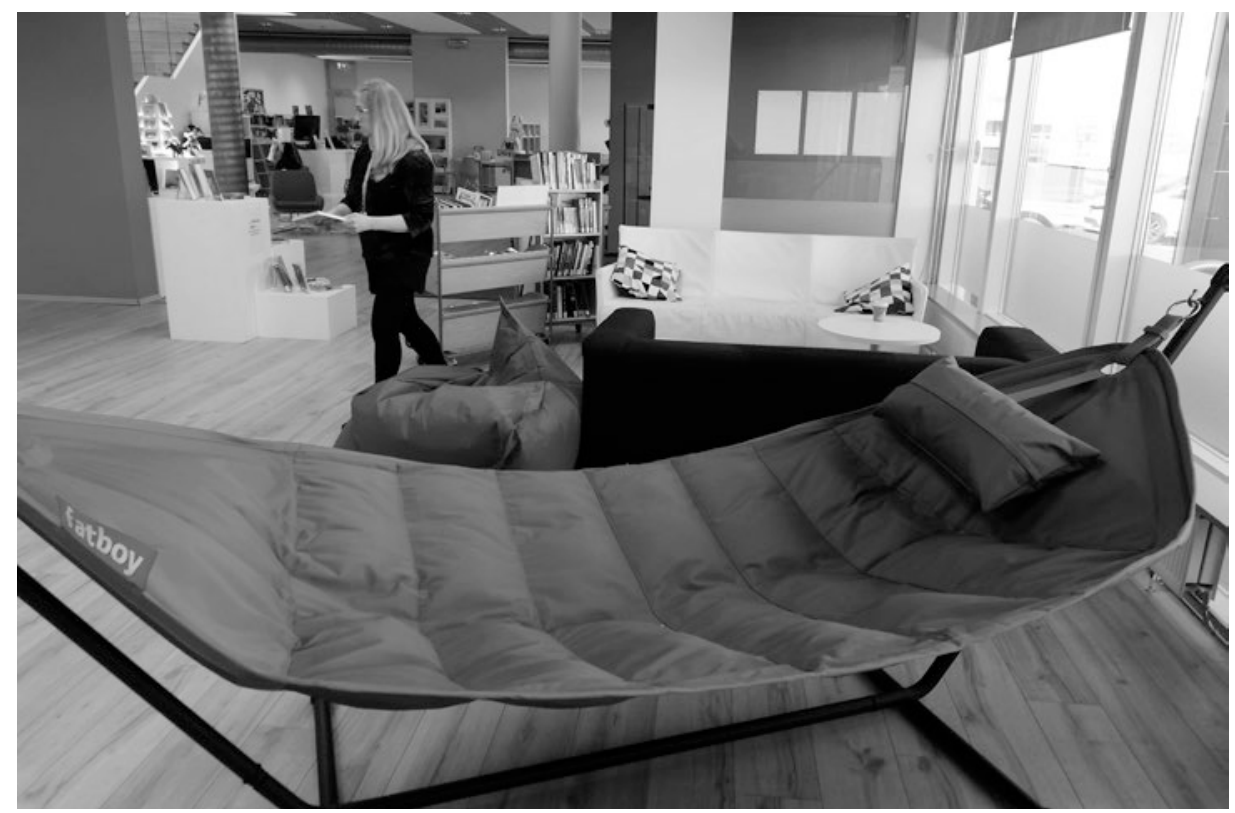

Slika 4. Viseća ležaljka u knjižničnom ogranku Spöngin 
U odnosu na hrvatske knjižnice postoji još jedna značajka usluga i programa koji su više od knjiga i tradicionalne knjižnične ponude. Naime na atraktivnost knjižnične ponude utječe i artoteka, usluga iznajmljivanja i prodaje, ali i promocije islandske suvremene umjetnosti u suradnji Gradske knjižnice s Udruženjem islandskih likovnih umjetnika. Slike se mogu posuditi na mjesec dana uz novčanu naknadu, koja se može otplaćivati i kao kredit do kupovne cijene. Glavna knjižnica i svi ogranci također nude The Library Shop, male knjižnične trgovine suvenirima, obrazovnim i zabavnim igračakama, platnenim torbama, bookmarkerima, slikovnicama i sl. U knjižničnom ogranku Gerðuberg nalazi se omanji restoran s hranom i pićem za posjetitelje, a u nekim drugim islandskim knjižnicama manji cafei ili pekarnice, što je u hrvatskim knjižnicama još uvijek velika rijetkost. ${ }^{40}$

U neposrednoj budućnosti Gradska knjižnica Reykjavik planira implementaciju koncepta tzv. Open libraries ili otvorenih knjižnica koje rade na principu samoposluge, bez knjižničara. Taj koncept proširio se iz Danske na druge nordijske zemlje. Konkretno, u slučaju Gradske knjižnice Reykjavik to znači da će korisnici moći posjetiti knjižnicu rano ujutro, prije nego na posao dođu zaposlenici, ili navečer, nakon završetka službenog radnog vremena. Također su u tijeku procesi lobiranja za zgradu glavne knjižnice kako bi u potpunosti bila posvećena knjižničnoj svrsi, a ne kao sada i arhivskoj i muzejskoj djelatnosti, te nakon renovacije bila otvorena za javnost 2023. godine, na 100. godišnjicu postojanja Gradske knjižnice Reykjavik.

\subsection{Programi i projekti}

Za hrvatsku praksu može biti inspirativna usporedba s inovativnim programima i projektima Gradske knjižnice Reykjavik, koji ističu suvremeno usmjerenje te knjižnice kao informacijsko-komunikacijskog središta i višenamjenskog mjesta koje promiče kulturu, obrazovanje i cjeloživotno učenje.

Programi i projekti Gradske knjižnice Reykjavik, koji zbog inovativnosti i aktualnosti mogu poslužiti kao primjer i model hrvatskim knjižnicama kako profilirati knjižnicu kao relevantno i polifunkcionalno središte u svojoj sredini, grupirani su u tri cjeline: očuvanje kulturne baštine i izgradnja kulture čitanja u digitalnom okruženju; poticanje i njegovanje interkulturnosti; knjižnica kao maker space ili prostor za učenje kroz kreativno stvaranje u različitim područjima djelovanja. Zajedničko im je obilježje primjena strategije suradnje i partnerstva s mnogobrojnim lokalnim i nacionalnim organizacijama i udrugama u osmišljavanju i realizaciji tih programa i projekata. Kao što ističe Andrea Wyman, mreža partnerstava i u ostalim je islandskim knjižnicama jedan od moćnih upravljačkih alata i koncepata u njihovu pozicioniranju u lokalnoj zajednici i društvu općenito. ${ }^{41}$ Iako hrvatske

$40 \quad$ Wyman, A. Nav. dj., str. 8.

41 Isto. 
knjižnice u svojem radu također rabe alate umrežavanja i partnerstva i osmišljavaju mnogobrojne inovativne i kreativne programe i projekta, usporedba s islandskom praksom može biti inspirativna u širenju dijapazona usluga.

\subsubsection{Očuvanje kulturne baštine i izgradnja kulture čitanja u digitalnom okru- ženju}

Programi očuvanja kulturne baštine i poticanja čitanja Gradske knjižnice Reykjavik ponajprije se temelje na bogatim i raznovrsnim zbirkama multimedijalne građe na islandskom i drugim jezicima - knjiga, popularnih i dokumentarnih filmova, glazbe, stripova. Pretraživanje te bogate knjižnične ponude omogućuje već spomenuti katalog Leitiris (usporedi poglavlje 2.4.), koji je više od knjižničnog kataloga budući da omogućuje pristup islandskom skupnom katalogu, pretplatama na elektroničke časopise, e-knjige, doktorske i magistarske radove i digitaliziranu građu te omogućuje obnovu posudbi, rezervacija, zahtjeva za građom i dr.

Uz ponudu nacionalne mrežne baze elektroničke građe članovi knjižnice imaju i mogućnost besplatne uporabe mrežne knjižnice Naxos, zbirke pretplatničkih usluga za streaming glazbe i filmova koje su dostupne institucijama i pojedincima bez vremenskog ograničenja. ${ }^{42} \mathrm{Na}$ raspolaganju su im milijuni skladbi stotina izdavačkih kuća i preko tisuću opera, baletnih predstava, koncerata i glazbenih filmova. ${ }^{43}$

\subsubsection{Reykjavik UNESCO-ov Grad književnosti}

Gradska knjižnica Reykjavik ima veliku ulogu u projektu Reykjavik UNESCO-ov Grad književnosti koji ističe važnu uloga središnjeg položaja književnosti u kulturnom životu grada i nacije, njezina povijesnog značenja i suvremene vrijednosti. Reykjavik je 2011. godine izabran za peti UNESCO-ov Grad književnosti zato što uspostavlja suvremeni koncept lokalne baštine koji uključuje građu, usluge i događanja, a zasniva se na suradnji knjižnice, muzeja i arhiva u promicanju kulturnih vrijednosti čitanja na inovativan način povezujući ga s novim tehnologijama, obrazovanjem i turizmom.

Projekt se sastoji od nekoliko segmenata. Islandski književni web mrežna je stranica posvećena islandskoj književnosti koja sadrži informacije o više od stotinu islandskih književnika i njihovim djelima te sakuplja i nudi na jednom mjestu uvid u književne kritike novih islandskih knjiga. ${ }^{44}$ The Reykjavik Culture Walks App mobilna je aplikacija, zbirka vođenih pješačkih tura po gradu kojima se na

\footnotetext{
42 Naxos online libraries. Dostupno na: https://www.naxosonlinelibraries.com/. [citirano: 202006-03].

43 The Reykjavík City Library. Dostupno na: https://borgarbokasafn.is/en. [citirano: 2019-11-15].

44 Literature Web. Dostupno na: https://www.bokmenntaborgin.is/en/literature-web/. [citirano: 2019-11-15].
} 
licu mjesta upoznaje prošlost i povijest Reykjavika. ${ }^{45}$ Treći je segment projekta tzv. Gröndalova kuća, tradicijska drvena vila nazvanu po vlasniku, piscu, umjetniku i znanstveniku Benediktu Gröndalu (1826. - 1907.). Kuća je u vlasništvu grada Reykjavika i vodi se kao književna kuća - muzej, ali i objekt za rezidencijalne boravke književnika i znanstvenika iz cijelog svijeta, a o njoj skrbi Gradska knjižnica.

\subsubsection{Vođene književne šetnje po Reykjaviku}

Gradska knjižnica provodi od 2003. godine posebno zanimljiv, originalan i zabavan način promocije islandskih književnika i književnosti pod nazivom Vođene književne šetnje po Reykjaviku. Šetnje osmišljavaju i vode knjižničari (na engleskom i islandskom jeziku), trenutno po motivima kriminalističkih romana islandskih autora pod nazivom Dark Deeds.$^{46}$ Tim programom knjižničari prikazuju grad kao književno mjesto u različitim vremenima i svakodnevnom okruženju (slika 5.).

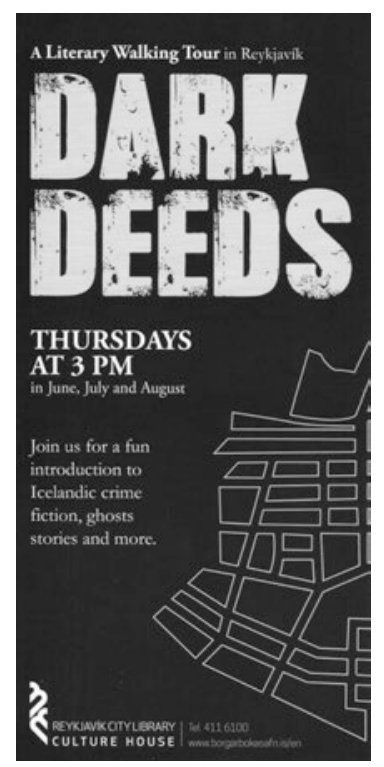

Slika 5. Pozivni letak na književne šetnje Dark Deeds

\footnotetext{
45 Reykjavik Culture Walks. Dostupno na: https://apps.apple.com/is/app/reykjavik-culturewalks/id1127253323; https://play.google.com/store/apps/details?id=com.rvk android. [citirano: 2019-11-15].

46 Ture započinju u glavnoj knjižnici svakog četvrtka u lipnju, srpnju i kolovozu. Cijena iznosi 1.500 ISK po osobi (oko 80 kuna), besplatne su za djecu do 18 godina. Obilazak se može rezervirati po dogovoru za grupe do 30, uz naknadu od 40.000 ISK (oko 2100 kuna).
} 


\subsubsection{3. Čitateljski klubovi}

Čitateljski klubovi djeluju u glavnoj knjižnici i svim ograncima, a funkcioniraju kao forumi za razmjenu mišljenja na temelju pročitanih knjiga. Razlikuju se po svojim oblicima, pa tako u jednom od svojih ogranaka knjižnica poziva korisnike na tzv. Book Chat, otvorenu raspravu o knjizi koju su upravo pročitali i žele ju preporučiti drugima ili potražiti preporuke za čitanje. U drugom ogranku ne traži se da se unaprijed pročita zadana knjiga, već je zadana tema, npr. što vas zanima o Božiću, ženska književnost i knjige s jakim heroinama, klasične dječje knjige, islandski romani i dr. Nije potrebna prethodna prijava, sudjelovanje je uz kavu besplatno.

Knjižnica također poziva svoje korisnike da u knjižničnim prostorima sami pokrenu vlastitu grupu u kojoj će se razgovarati o knjigama, glazbenim albumima ili filmovima. Ako korisnici žele preporučiti neku knjigu koju su sami pročitali, knjižnica ih poziva da to učine i u knjižničnom podcast studiju u glavnoj knjižnici Grófinn. Neki ogranci osiguravaju i tzv. sobe za pisanje, slobodni prostor za pisce koji rade na vlastitim projektima ili se povezuju s istomišljenicima.

\subsubsection{Sati kave u Gradskoj knjižnici}

Forum pod nazivom Sati kave u Gradskoj knjižnici nudi korisnicima susrete s gostima s kojima raspravljaju o različitim temama ili knjigama. Autori, prevoditelji i čitatelji dijele svoje iskustvo čitanja s drugim gostima. S predavačima iz različitih područja razgovara se također i o životnim stilovima, npr. o zdravlju, sreći, okolišu, kao i o poželjnim vrijednostima u životu. Usto knjižnica poziva pjesnike da čitaju svoju poeziju, čija je objava na Islandu u porastu. Također iskusni putnici dijele s publikom svoje priče o putovanjima i pružaju uvid u različite kulture.

\subsubsection{Projekt NORD}

Gradska knjižnica Reykjavik organizira niz programa za poticanje čitanja kod djece i mladih, od obiteljskih okupljanja s bebama i malom djecom do individualnih i grupnih, organiziranih dolazaka mladih. Između ostaloga, na taj se način uključuje u nacionalne napore preveniranja i suzbijanja negativnih trendova opadanja čitateljskih kompetencije mladih na koje upozoravaju rezultati istraživanja pismenosti PISA (Program for International Student Assessment), ${ }^{47}$ a kojima ne

47 U OECD-ovu istraživanju PISA za 2018. godinu testirano je oko 600000 petnaestgodišnjaka u 79 zemalja svijeta, a rezultati pokazuju da je učinak islandskih učenika znatno pogoršan u 2018. godini u usporedbi s 2009. godinom s obzirom na ispodprosječne rezultate u čitalačkoj pismenosti i prirodoslovnoj pismenosti, uz iznadprosječne rezultate u matematici. Usp. Icelandic students below average in reading. // Culture and Living, Iceland Monitor, 3 Dec 2019. Dostupno na: $\mathrm{https}$ ://icelandmonitor.mbl.is/news/culture and living/2019/12/03/icelandic students below average_in_reading/. [citirano: 2019-11-15].

Uspore $\overline{d b}$ - radi, hrvatski učenici ostvarili su ispodprosječne rezultate u sva tri ispitna područja, a u čitalačkoj su pismenosti na 29., a Island na 35. mjestu u sveukupnoj ljestvici. Usp. Objavljeni 
odolijeva ni Island bez obzira na svoj fokus na čitanje, knjige i književnost od davnih vremena. Iako se rezultati PISA-istraživanja neposredno tiču obrazovnih politika pojedinih zemalja, islandske knjižnice doprinose promociji važnosti čitanja i književnosti kod djece i mladih.

Po visini dobivenih financijskih sredstava, ekstenzivnosti, složenosti i međunarodnoj suradnji trenutno se ističe projekt NORD za poticanje čitanja kod djece i tinejdžera u dobi od 10 do 16 godina, skupine koja u toj dobi tradicionalno napušta čitanje zbog drugih interesa. ${ }^{48}$ Polazna je točka projekta širenje okvira tradicionalne literature i povijesti kako bi se kroz različite medije i nove načine povezivanja književnosti s digitalnim tehnologijama doprijelo do šire skupine mladih. Cilj je projekta potaknuti mlade da se uključe u stvaranje kreativne interakcije između literature, kulturne baštine, tehnologije i rasprave o klimi. Polazište je književni predložak koji kroz priču o djevojci Nord rabi nordijsku mitologiju kao zajedničko kulturno nasljeđe nordijskih zemalja. ${ }^{49}$ Glavna junakinja prolazi kroz zahtjevan razvojni proces samospoznaje, a cilj joj je spasiti svijet, čime se stvaraju poveznice s današnjim glavnim pitanjima i ozbiljnim izazovima s kojima se mladi danas suočavaju, kao što su klimatske promjene i njihov utjecaj na ekosustave Zemlje i buduće generacije. Projekt je višeslojan te između ostaloga na različite načine povezuje multimedijske sadržaje dajući mogućnost za implementaciju u školske predmete, poput materinjeg jezika, prirodnih i društvenih znanosti, programiranja, vizualnih umjetnosti, dizajna i životnih vještina.

\subsubsection{Mnoga lica knjiga}

Popularizacija knjiga među mladima provodi se i kroz program kojemu je cilj preporuka čitanja na društvenim mrežama. Mladi putem vlastitih grafičkih reinterpretacija naslovnica knjiga i njihovih objava na Instagramu pozivaju druge da prepoznaju o kojoj je knjizi riječ. Postovi se dijele petkom uz popis preporučenih knjiga za čitanje.

\subsubsection{Interkulturni programi}

Interkulturni programi Gradske knjižnice Reykjavik odgovor su na promijenjeni sastav stanovništa Islanda u proteklih nekoliko desetljeća. Svojim programima knjižnica podržava interkulturnu politiku grada Reykjavika i strategiju

rezultati istraživanja PISA - pogledajte gdje je Hrvatska. Dostupno na: http://hr.n1info.com/Vijesti/a464862/Objavljeni-rezultati-istrazivanja-PISA-pogledajte-gdje-je-Hrvatska.html. [citirano: 2019-11-15].

48 Söguheimur NORD hlýtur hæsta styrk Barnamenningarsjóðs 2019. Dostupno na: https:// borgarbokasafn.is/starfid-a-safninu/tilkynningar/soguheimur-nord-hlytur-haesta-styrkbarnamenningarsjods-2019. [citirano: 2020-04-07].

49 NORTH - a digital tale. Dostupno na: http://www.nord-app.com/intro. [citirano: 2019-11-15]. 
koja se temelji na politici ljudskih prava te podupire kulturnu i etničku raznolikost. ${ }^{50}$ Danas imigranti prve i druge generacije čine 15,6 posto islandske populacije s tendencijom rasta. ${ }^{51}$ Najviše je useljenika iz Poljske tako da im knjižnica na svojoj mrežnoj stranici pruža informacije na poljskom ${ }^{52}$, potom iz Litve i Filipina.

Kristín R. Vilhjálmsdóttir, voditeljica interkulturnih programa u Gradskoj knjižnici Reykjavik, ističe da knjižnica provodi u praksu svoje usmjerenje spram poštivanja i podupiranja interkulturnosti islandskog društva tako što osmišljava i provodi programe i projekte u kojima umjetnost i kreativnost čine temelj suradnje $\mathrm{s}$ različitim članovima zajednice. U njihovu provođenju surađuje s mnogobrojnim partnerima - socijalnim službama, školama, fakultetima, organizacijama i pojedincima strancima iz cijelog svijeta koji žive u Reykjaviku. Glavni je cilj da posjeti knjižnici postanu dio svakodnevnog života imigranata, kao i ostalih građana te poslati poruku da su knjižnični programi i usluge dostupne svima. ${ }^{53} \mathrm{U}$ nastavku se daje uvid u operacionalizaciju tih smjernica u konkretnim programima i projektima.

\subsubsection{Women story circle}

Program okuplja žene iz raznih zemalja, a rezultat je suradnje Gradske knjižnice i organizacije W.O.M.E.N. koja na Islandu promiče prava žena. Žene se nalaze u knjižnici, razmjenjuju priče, iskustva i kulturu zemalja iz kojih dolaze te sudjeluju u kreativnim aktivnostima i vježbanju islandskog jezika. Na slici 6. prikazan je jedan takav zajednički likovni rad žena izrađen aboridžinskom metodom točkica. Zanimljivost je da su pojedini radovi prodani jednoj islandskoj tvornici kave, koja ih rabi za ilustraciju ambalaže u kojoj se kava prodaje u trgovinama, što predstavlja primjer uspješnog, inovativnog marketiranja knjižnice kao kreativnog mjesta za stvaranje.

\footnotetext{
50 The world is here. // Reykjavik City Department of Education and Youth policy on multicultural education and leisure, 2014. Dostupno na: https://reykjavik.is/sites/default/files/ fjolmenningarstefna_uppsett_enska_n.pdf. [citirano: 2019-11-15].

51 Hafstað, V. More than 50,000 immigrants in Iceland.//Iceland Monitor, 2 Dec (2019). Dostupno na: https://icelandmonitor.mbl.is/news/news/2019/12/02/more_than_50_000_immigrants_in_ iceland/.[citirano: 2019-11-15].

52 Pierwszy raz w bibliotece? Dostupno na: https://borgarbokasafn.is/en/pierwszy-raz-wbibliotece. [citirano: 2019-11-15].

53 Vilhjálmsdóttir, K. R. The new human landscapes of Iceland. // SLQ, 1-2(2016). Dostupno na: http://slq.nu/indexf46f.html?article=volume-49-no-1-2-2016-4. [citirano: 2019-11-15].
} 


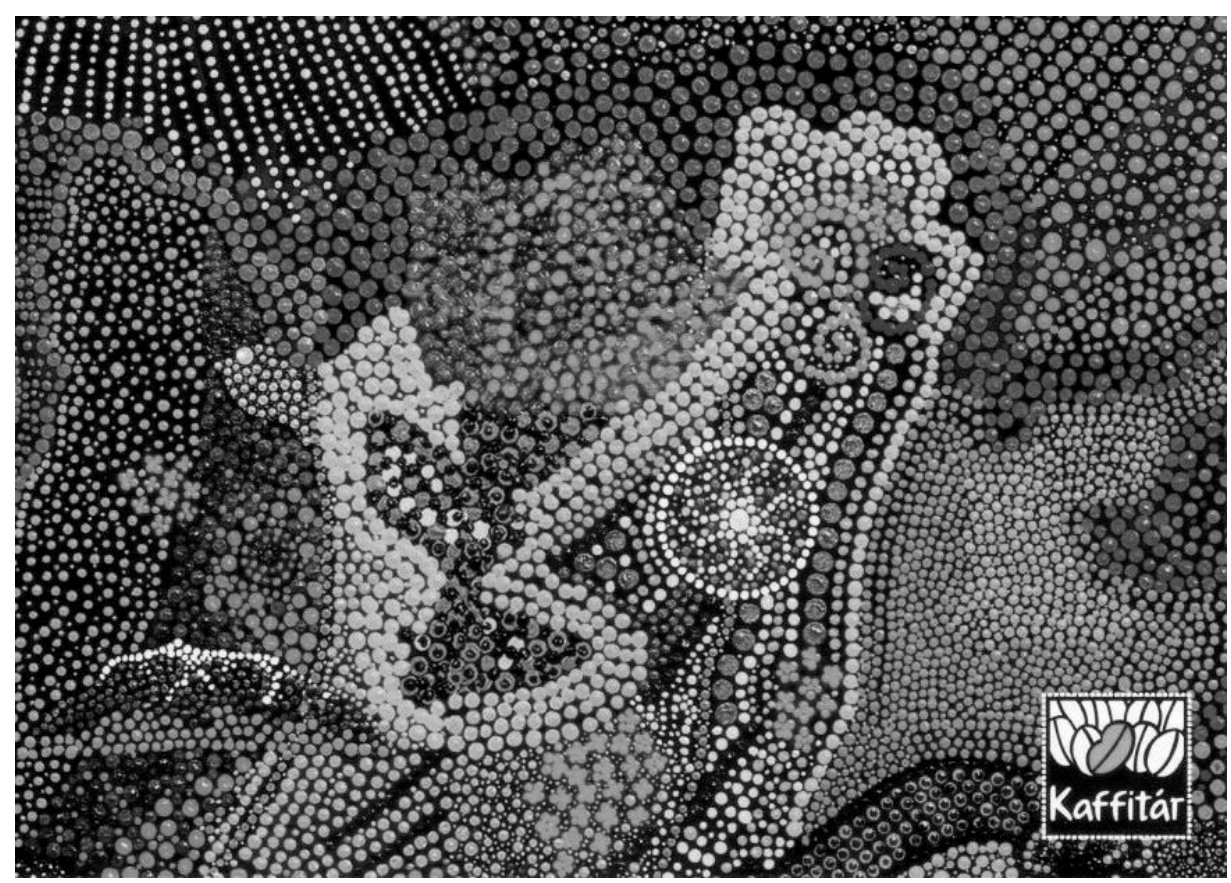

Slika 6. Zajednički likovni rad članica Women story circle (preslika promotivne razglednice)

\subsubsection{Café lingua - Svijet jezika!}

Café Lingua platforma je za sve one koji žele unaprijediti svoje jezične vještine, islandski ili druge jezike, mjesto je za komuniciranje na različitim jezicima, kao i uvod u različite kulture. Cilj je programa širiti i doprinositi jezičnom krajoliku Reykjavika. Program organizira Gradska knjižnica u svojim prostorima u partnerstvu s lokalnim jezičnim centrom, a suradnici su i fakulteti za jezike i kulture, islandski kao drugi jezik, ruski i istočno-europski studiji s Islandskog sveučilišta, studentske udruge i pojedinci stranci koji žive na Islandu.

\subsubsection{Obiteljska okupljanja u knjižnici}

Program podupire integraciju u islandsko društvo. Gradska knjižnica Reykjavík poziva obitelji s djecom u dobi od 0 do 6 godina da dođu u knjižnicu na programe o različitim temama koje su važne u odrastanju i odgoju djeteta, kao i da predstave svoju osobnu kulturu koja nije nužno vezana uz nacionalnu kulturu. 


\subsubsection{Upoznavanje s knjižnicom}

Program je namijenjen učiteljima i odraslima koji uče islandski kao drugi jezik. Polaznici zajedno rade na pronalaženju korisnih i zanimljivih informacija za učenje na opušten način. Program se također nudi i onima koji nemaju veliko znanje islandskog te ih povezuje s osobama koje dobro razumiju i govore islandski jezik.

\subsubsection{5. Što je u vijestima?}

Gradska knjižnica Reykjavik organizira taj program u partnerstvu s radijskim programom na engleskom jeziku. Voditelj radijskog programa vodi malu grupu sudionika kroz program The Week in Iceland $\mathrm{s}$ čestim pauzama za raspravu i analizu. Riječ je o forumu na kojemu se kritički analiziraju informacije u novinama. Kao takav, program doprinosi kritičkoj i medijskoj pismenosti, razumijevanju društvenog konteksta u kojima vijesti nastaju te razlikovanju istinih od fake ili lažnih vijesti pa kao takav također može poslužiti kao primjer hrvatskim knjižnicama.

\subsubsection{Kids Study}

Kids Study suradnički je projekt Gradske knjižnice i Crvenog križa. Volonteri Crvenog križa pružaju potporu i podršku osnovnoškolcima od četvrtog do desetog razreda u učenju i pisanju zadaća uz istodobno upoznavanje s uslugama koje knjižnice nude u vezi s učenjem, hobijima i slobodnim vremenom. Cilj je projekta izjednačiti mogućnosti za svu djecu na Islandu bez obzira na podrijetlo, a fokus je na uključivanju učenika u zajedničko učenje i zabavu. Usluga se nudi u svim knjižničnim ograncima.

\subsubsection{Knjižnica kao maker space}

Slijedeći suvremene trendove u međunarodnom knjižničarstvu, Gradska knjižnica Reykjavik sve se više pozicionira u svojoj sredini kao suvremeni maker space ili prostor za učenje kroz kreativno stvaranje u različitim područjima. Budući da nastoji biti vodeća u svojoj zajednici u pružanju pristupa modernoj tehnologiji i opremi, ta knjižnica u tu svrhu osigurava prostore u kojemu djeca i odrasli mogu imati pristup edukaciji, eksperimentiranju, stvaranju i otkrivanju novih stvari pomoću tehnologije. Knjižnica također osigurava prostor za ručne radove (pletenje i šivanje). U nastavku se navodi nekoliko najaktualnijih programa i projekata koji ilustriraju to strateško usmjerenje Gradske knjižnice Reykjavik.

\subsubsection{1. Želiš li stvarati?}

Osim prostora za odvijanje projekta za mlade NORD s ciljem stvaranja kreativne interakcije među literaturom, kulturnom baštinom, tehnologijom i ekologi- 
jom, u ogranku Gerðuberg djeca i mladi na raspolaganju imaju prostor za upoznavanje s novom tehnologijom, konkretno s micro:bitovima za programiranje, što je sve raširenija praksa i u hrvatskim knjižnicama. Slično hrvatskim knjižnicama, Gradska knjižnica Reykjavik poziva korisnike da u radionici eksperimenata nauče rabiti 3D-printer te kako izrezati naljepnice u programu Scratch pod vodstvom knjižničara. Nije potrebno prethodno znanje, a dobrodošli su djeca i roditelji. Pruža se osobna poduka, jedan na jedan ili pak grupna poduka.

\subsubsection{Kompan-studio}

U hrvatskim knjižnicama za sada ne postoji praksa koju njeguje Gradska knjižnica Reykjavik, a to je ponuda uporabe malog podcast studia u zgradi glavne knjižnice gdje korisnici mogu besplatno rabiti mikrofone, slušalice i računala $s$ pristupom aplikacijama. Istovremeno četiri osobe mogu stvarati i slušati snimke i audiomikseve. Gradska knjižnica i sama proizvodi podcast zapise sa svojih događanja te ih pohranjuje u vlastiti radiorepozitorij.

\subsubsection{Prostor za stvaranje glazbe}

Knjižnica pokreće i maker space za stvaranje glazbe. Primjer hrvatskim knjižnicama može biti i proces domišljanja te usluge, čijoj je implementaciji prethodilo istraživanje metodom fokus-grupe glazbenika i mladih zainteresiranih za učenje stvaranja glazbe. Na temelju njihovih savjeta oblikovan je program radionica na kojima će korisnici moći na jednostavan način naučiti sve što je potrebno za sastavljanje kratkih pjesama prilagođenih plesu uz pomoć računalnih aplikacija i programa sa širokim spektrom instrumenata, ritmova i glazbenih oblika.

\subsubsection{Radionice ručnih radova}

Uz radionice uporabe nove tehnologije, knjižnica nudi i radionice tradiconalnih ručnih radova, konkretno pletenja i šivanja, što također može biti zanimljivo hrvatskim knjižnicama u kojima je to vrlo rijetka praksa. Poziva korisnike da jedni od drugih uče plesti uz druženje i kavu. Kao što je ogranak Gerðuberg fokusiran na kreativno stvaranje pomoću novih tehnologija, tako ogranak Árbær u ponudi ima logistiku za izradu ručnih radova, konkretno kutak za šivanje i popravak tekstila. Konkretno, osigurana su dva standardna šivaća stroja i jedan overlock stroj (istovremeno šije, porubljuje i reže tkaninu). Pretpostavlja se da su oni koji rabe šivaće strojeve uglavnom samostalni, ali pomoć obuke nudi se u posebnim događanjima pod nazivom Šivanje uz kavu. U suradnji s nekoliko udruga provodi se projekt šivanja vrećica za kupovinu, koje se potom distribuiraju i prodaju u knjižnicama kao suveniri, na bazenima za plivanje i drugim javnim mjestima. Uzorci i tkanina za njihovu izradu dostupni su u knjižnici. 


\section{Zaključak}

$\mathrm{Na}$ temelju neposrednog uvida u rad Gradske knjižnice Reykjavik metodom job shadowing, kao i analizom dostupne literature, benchmarking ili usporedba $\mathrm{s}$ islandskim modelom knjižničnih usluga može poslužiti hrvatskoj knjižničnoj praksi uvođenje promjena i poboljšanje rada. ${ }^{54}$ Riječ je o inovativnom i kreativnom primjeru knjižnične prakse koji se uspio prilagoditi zahtjevima suvremenog društva. Od njega se može učiti kako odgovoriti na bitne izazove s kojima se sučavaju knjižnice u svijetu bez obzira na specifični kulturno-povijesni okvir i kontekst djelovanja - ograničene financijske, ljudske i prostorne resurse s jedne strane, a sve sofisticiranije zahtjeve korisnika u digitalnom okruženju s druge strane. Usprkos visokim standardima svojeg rada, hrvatske knjižnice, odgovarajući na te izazove, mogu naučiti od islandskih kako se vještije koristiti strategijama suradnje i umrežavanja na lokalnoj, regionalnoj, a posebice nacionalnoj razini za racionalnije, fleksibilnije i učinkovitije poslovanje. Suradnja je zakonska obveza islandskih knjižnica, a ukorijenjena je u tradiciju zadaće javnog prosvjećivanja nordijskih knjižnica općenito, kao i jasno određene uloge u nacionalnim strateško-političkim dokumentima. Pozicionirane su naime kao važni čimbenici u razvoju suvremenog informacijskog društva na svim područjima života, a ne samo kulture kao u Hrvatskoj.

Na primjeru Gradske knjižnice Reykjavik načela racionalnog, fleksibilnog i učinkovitog poslovanja operacionalizirani su na svim razinama - od organizacijske strukture, organizacijske kulture (s primjenom suvremenih upravljačkih koncepata $\mathrm{i}$ alata poput design thinkinga), fizičkog prostora, knjižničnih zgrada i opreme, nabavne politike, stručne obrade, cirkulacije građe, međuknjižnične posudbe do kulturno-edukativnih programa i projekata. Islandske knjižnice pri tome vještije od hrvatskih knjižnica rabe prednosti informacijsko-komunikacijske tehnologije, posebno u nacionalnoj koordinaciji stručne obrade i cirkulacije građe te rutinskim, manipulativnim poslovima, u kojima je rad stručnjaka zamijenjen samoposlugom korisnika kako u fizičkom knjižničnom prostoru, tako i u uporabi digitalnih knjižničnih usluga (npr. mobilnim aplikacijama, nacionalnim skupnim e-katalogom). Najvažnija pouka hrvatskim knjižnicama na temelju islandske prakse imperativ je

54 Kako je cilj učenja metodom job shadowing primjena primjera tuđe dobre prakse u vlastitom radu po povratku u vlastito radno okruženje, sudionica mobilnosti, autorica ovog rada, u kraćem razdoblju primijenila je nova znanja u području očuvanja kulturne baštine, izgradnje kulture čitanja i uključenosti građana kroz primjenu novih digitalnih alata i metoda u dvama projektima svoje knjižnice - u suradnji s volonterima srednjoškolcima čitanje štićenicima Doma za starije i nemoćne te provođenje kreativnog natječaja „Koprivnički krimić“ s ciljem povezivanja literarnog stvaralaštva s kulturnim turizmom, tj. vođenim literarnim šetnjama po Koprivnici po motivima nagrađenih kratkih priča. Posebno valja naglasiti kako rad na prijavi projekta na natječaj programa Erasmus+ Europske unije iziskuje zahtjevne i opsežne pripreme te vrijeme koje je za to trebalo izdvojiti. Međutim učenje od prakse islandskih knjižnica metodom job shadowing opravdava taj trud jer je ojačalo ne samo invidvidualna znanja i kompetencije sudionice već su i projektom dodatno ojačani kapaciteti i međunarodna dimenzija organizacije u kojoj radi. 
nacionalne koordinacije u osiguravanju ravnopravne dostupnosti i jednake kvalitete knjižničnih usluga u fizičkom i elektroničkom obliku korisnicima i u najmanjim, udaljenim naseljima koje nemaju stacionirane knjižnice pomoću učinkovite međusobne suradnje i primjene informacijsko-komunikacijske tehnologije. To se u Hrvatskoj odnosi kako na potrebu dobro usustavljenog mrežnog nacionalnog knjižničnog sustava sa skupnim katalogom i zajedničkim pretraživačem fondova svih knjižnica, tako i na zajedničku nabavu i uporabu elektroničkih servisa (digitalizirane kulturne baštine, e-knjiga, glazbe, filmova i s1.), ali i redefiniranje i modernizaciju međuknjižnične posudbe na lokalnoj, regionalnoj i nacionalnoj razini. Od islandskih knjižnica treba preuzeti i organizacijski model konzorcija na nacionalnoj razini u izgradnji zajedničkog, učinkovitog mrežnog knjižničnog sustava te suradnju s drugim baštinskim ustanovama - muzejima i arhivima - kako bi se zbirke učinile što vidljivijima i korištenima te povećao obuhvat stanovništva u uporabi knjižnica. Obuhvat stanovništva u hrvatskim knjižnicama, koji iznosi samo 12 posto u odnosu na islandskih 50 posto, povećala bi i zakonska obveza besplatne članarine (bar za najpotrebitije skupine korisnika - npr. djecu, mlade, starije, nezaposlene).

Hrvatske knjižnice ravnopravno pariraju islandskim knjižnicama na lokalnoj razini kao socijalno-integrirajući faktor u razvoju svojih zajednica ponudom kulturnih i obrazovnih programa i projekata te primjenom strategije suradnje $\mathrm{i}$ umrežavanja s drugim organizacijama, udrugama i pojedincima kako bi se ti sadržaji realizirali dijeljenjem kadrovskih, financijskih i prostornih resursa. Od Gradske knjižnice Reykjavik može se naučiti na koji način inovativnim konceptima rada redefinirati ulogu knjižnica u digitalnom okruženju te kojim se partnerima obratiti za suradnju u programima i projektima očuvanja kulturne baštine, poticanja čitanja, podupiranju interkulturnosti te kreativnom stvaralaštvu koje profilira knjižnicu kao maker space. Taj najnoviji koncept pozicionira knjižnice kao predvodnice u povezivanju dostupnosti najnovije tehnologije i primjene $u$ svakodnevnom životu. Također se može naučiti kako identificirati i rješavati krucijalne društvene probleme zajednice, konkretno na primjerima integracije imigranata u u društvo ili podrške mladima u zadržavanju tradicije visoke kvalitete čitateljskih navika i vještina, koje Island brandiraju u svijetu kao naciju čitatelja.

Specifičnosti kulturnog, političkog, ekonomskog i društvenog okruženja, kao i specifična tradicija i povijest, a posebice radna i organizacijska praksa islandskih knjižnica ukazuje da tuđe iskustvo može poslužiti kao inspiracija za vlastito osmišljavanje sličnih usluga, programa i projekata. Samo prilagođeni specifičnim potrebama i mogućnostima pojedinih nacionalnih sredina, poput hrvatske, mogu doprinijeti povezivanju napora da se zadovolje specifične nacionalne potrebe s globalnim, zajedničkim komponentama suvremenog društva vezanima ponajprije uz prožimanje svih vidova života komunikacijsko-informacijskom tehnologijom. 


\section{LITERATURA:}

Antoljak, V.; M. Kosović. Design thinking za nedizajnere: kako riješiti poslovne probleme i uspješno inovirati. Zagreb: Školska knjiga: Sense savjetovanja, 2018.

Borgarbókasafn Reykjavikur. // Nordic public libraries: the Nordic cultural sphere and its public libraries / editor Jens Thorhauge etc. Københaven: The Danish National Library Authority, 2002., str. 45-47.

Gegnir. Dostupno na: www.gegnir.is. [citirano: 2019-11-15].

Hafstað, V. More than 50,000 immigrants in Iceland. // Iceland Monitor, 2 Dec (2019). Dostupno na: https://icelandmonitor.mbl.is/news/news/2019/12/02/more than_50_000_immigrants_in_iceland/.[citirano: 2019-11-15].

Hannesdóttir, S. K. Books and reading in Iceland in a historical perspective. // Libraries \& Culture 28, 1 (1993), ), 13-21.

Hvar.is - Icelandic consortium for electronic subscriptions. Dostupno na: https://hvar.is/ english. [citirano: 2019-11-15].

Iceland in figures 2018: volume 23. Reykjavík: Statistics Iceland, 2019.Dostupno na: https:/hagstofan.s3.amazonaws.com/media/public/2019/7bc8b111-7479-4739-8aa5-a9b9f5dcf3eb.pdf. [citirano: 2019-11-15].

Icelandic students below average in reading. // Icelandic Students below Average in Reading. // Culture and Living, Iceland Monitor, 3 Dec 2019. Dostupno na: https:// icelandmonitor.mbl.is/news/culture_and_living/2019/12/03/icelandic_students_below_average_in_reading/. [citirano: $2019-11-15]$.

Island. // Mrežno izdanje Hrvatske enciklopedije Leksikografskog zavoda Miroslav Krleža. Dostupno na: http://www.enciklopedija.hr/natuknica.aspx?id=27933. [citirano: 2019-11-15].

Kjartansdóttir, A. Iceland. // World Encyclopedia of Library and Information Services: third edition. Chicago: American Library Association, 1993., str. 160- 161.

Konzorcij. // Mrežno izdanje Hrvatske enciklopedije Leksikografskog zavoda Miroslav Krleža. Dostupno na: http://www.enciklopedija.hr/natuknica.aspx?id=33006. [citirano: 2019-11-15].

Leitir.is. Dostupno na: http://leitir.is.. [citirano: 2019-11-15].

Libraries and archives. Dostupno na: https:/www.island.is/en/education_and_society/ culture_and_the_arts/libraries_and_archives/. [citirano: 2019-11-15].

Libraries and open access to databases. Dostupno na: https://www.cityofliterature.nl/en/ cities/reykjavik/. [citirano: 2019-11-15].

Literature Web. Dostupno na: https://www.bokmenntaborgin.is/en/literature-web/. [citirano: 2019-11-15]. 
Lowrie, J. E. School libraries and media centres. // Encyclopedia of library history / edited by Wayne A. Wiegand and Donald G. Davis. New York; London: Routledge Taylor \& Francis Group, 2013., str. 564.

Magnúsdóttir, M. Community of cataloguers in Iceland. // Scandinavian Library Quaterly, 1-2(2016), 42-44. Dostupno na: http://slq.nu/wp-content/uploads/2016/06/ SLQ-1-2.14.6.pdf. [citirano: 2019-11-15].

Marić, A. Književni Island uživa uz tradicionalnu božićnu "poplavu knjiga" - Jolabokaflod (Christmas Book Flood). Dostupno na: https://citajknjigu.com/knjizevni-island-uziva-uz-tradicionalnu-bozicnu-poplavu-knjiga-jolabokaflod-christmas-book-flood/ [citirano: 2019-11-15].

Naxos online libraries. Dostupno na: https://www.naxosonlinelibraries.com/. [citirano: 2020-06-03].

Najčešća pitanja o Comenius aktivnostima: 11. Što je ,job shadowing”?.Dostupno na: http://arhiva.mobilnost.hr/index.php?id=202. [citirano: 2020-04-05]

NORTH - a digital tale. Dostupno na: http://www.nord-app.com/intro. [citirano: 201911-15].

Objavljeni rezultati istraživanja PISA - pogledajte gdje je Hrvatska. Dostupno na: http:// hr.n1info.com/Vijesti/a464862/Objavljeni-rezultati-istrazivanja-PISA-pogledajte-gdje-je-Hrvatska.html. [citirano: 2019-11-15].

Ólafsson, S. Iceland Consortia for electronic subscription. // Nordic public libraries in the knowledge society / J. H. Larsen (Ed.). København: Danish National Library Authority, 2006., str. 50-51.

Pierwszy raz w bibliotece? Dostupno na: https://borgarbokasafn.is/en/pierwszy-raz-w-bibliotece. [citirano: 2019-11-15].

Publishing. // Reykjavik. Dostupno na: https://www.cityofliterature.nl/en/cities/reykjavik/. [citirano: 2019-11-15].

Requirements list for a new library system (draft). Consortium of Icelandic libraries 19/2/2018. Dostupno na:https://www.landskerfi.is/sites/default/files/requirements list_for_a_new_library_system_draft___consortium_of_icelandic_libraries.pdf. [citirano: 2019-11-15].

Reykjavík - City of literature. Dostupno na: https://www.cityofliterature.nl/en/cities/ reykjavik/. [citirano: 2019-11-15].

Reykjavík City Library Culture Houses. Dostupno na: https://borgarbokasafn.is/en/bokasofn. [citirano: 2019-11-15].

Reykjavik Culture Walks. Dostupno na: https://apps.apple.com/is/app/reykjavik-culture-walks/id1127253323; https://play.google.com/store/apps/details?id=com.rvk android. [citirano: 2019-11-15].

Sabolović-Krajina, D. Inkluzivne knjižnične usluge na primjerima Gradske knjižnice Rejkyavik i Knjižnice i čitaonice „Fran Galović“ Koprivnica. Dostupno na: https:// 
ec.europa.eu/epale/hr/blog/posjet-gradskoj-knjiznici-reykjavik://ec.europa.eu/epale/hr/blog/inkluzivne-knjiznicne-usluge-na-primjerima-gradske-knjiznice-rejkyavik-i-knjiznice-i-citaonice. [citirano: 2019-11-15].

Sabolović-Krajina, D. Posjet Gradskoj knjižnici Reykjavik u okviru programa Erasmus+, 16.-24.6.2018. // Svezak 21(2019), 96-98. Dostupno na: http://www.drustvo-knjiznicara-bpkp.hr/svezak/svezak21/Svezak_21_2019.pdf. [citirano: 201911-15].

Sarpur. Dostupno na: http://www.sarpur.is. [citirano: 2019-11-15].

Söguheimur NORD hlýtur hæsta styrk Barnamenningarsjóðs 2019. Dostupno na:https:// borgarbokasafn.is/starfid-a-safninu/tilkynningar/soguheimur-nord-hlytur-haesta-styrk-barnamenningarsjods-2019. [citirano: 2020-04-07].

Sveinsdóttir, S.; S. Hauksdóttir. Annual report from the Consortium of Icelandic Libraries for IGeLU National User group (INUG) 2018. Dostupno na:https://igelu. org/wp-content/uploads/2018/08/Iceland-INUG-report-2018.pdf. [citirano: 201911-15].

The Book-Flood-Before- Christmas. // Reykjavik.Dostupno na: https://www.cityofliterature.nl/en/cities/reykjavik/. [citirano: 2019-11-15].

The Reykjavík City Library. Dostupno na: https://borgarbokasafn.is/en. [citirano: 201911-15].

The world is here. // Reykjavik City Department of Education and Youth policy on multicultural education and leisure, 2014. Dostupno na:https://reykjavik.is/sites/default/ files/fjolmenningarstefna_uppsett_enska_n.pdfTorfadóttir, A. G. [citirano: 2019-11$15]$.

Thorhauge, J. The Nordic cultural sphere and the public libraries. // Nordic public libraries: The Nordic cultural sphere and its public libraries / editor Jens Thorhauge. Kobenhaven: The Danish National Library Authority, 2002., str. 9-12.

Torfadóttir, A.G. Borgarbókasafn Reykjavikur. // Nordic public libraries: the Nordic cultural sphere and its public libraries / editor Jens Thorhauge. Københaven: The Danish National Library Authority, 2002. Str. 45-47

Vilhjálmsdóttir, K. R. The new human landscapes of Iceland. // SLQ 1-2(2016). Dostupno na: http://slq.nu/indexf46f.html?article=volume-49-no-1-2-2016-4 [citirano: 2019-11-15]. 